\title{
Analitiese konsepte in middel-Foucault
}

\author{
Author: \\ Johann Beukes ${ }^{1}$ \\ Affiliation: \\ ${ }^{1}$ Departement of Philosophy, \\ University of Johannesburg, \\ South Africa

\section{Correspondence to:} \\ Johann Beukes \\ Email: \\ jbeukes@vodamail.co.za \\ Postal address: \\ PO Box 784849, Sandton \\ 2146, South Africa \\ Dates: \\ Received: 17 Feb. 2011 \\ Accepted: 14 Sept. 2011 \\ Published: 07 Feb. 2012 \\ How to cite this article: \\ Beukes, J., 2012, 'Analitiese \\ konsepte in middel-Foucault', \\ HTS Teologiese Studies/ \\ Theological Studies 68(1), \\ Art. \#1035, 17 pages. http:// \\ dx.doi.org/10.4102/hts \\ v68i1.1035
}

C) 2012. The Authors. Licensee: AOSIS OpenJournals. This work is licensed under the Creative Commons Attribution License.
Analytic concepts in middle Foucault. This article investigates prominent analytic concepts in the philosophical historiographies of Michel Foucault (1926-1984), with specific regards to the work done in the middle phase of his career. These concepts accentuate the relation between history, power and contingency within the context of social inquiry. The author qualifies a particular order in the isolation of these concepts from the middle part of Foucault's oeuvre: the notion of present history is introduced as the central concept in Foucault's analyses from this period. It is argued that the notion of present history sustains Foucault's other unique historiographical and socio-diagnostic tools from the particular period, namely archaeology, genealogy, discourse and power analysis. The article contributes to Foucaultian scholarship by periodising these concepts within the larger oeuvre, without subordinating Foucault to the parameters of his own 'method'.

\section{Inleiding}

Hierdie artikel word opgedra aan prof. dr P.M. Venter, 'n onberispelike leermeester in die teologie, by wie ek soveel geleer het van sowel kritiese teologie as sagsinnige menswees. Ek dank God vir prof. Venter se voorbeeld, leiding en inspirasie oor bykans drie dekades heen.

Michel Foucault (1926-1984) was professor in die Geskiedenis van Denksisteme aan die Collège de France in Parys vanaf 1970. In die 14 jaar wat hy dieleerstoel beklee het, ook vanuit'n verskeidenheid van Franse en Europese universiteite die voorafgaande 13 jaar, het Foucault 'n omvangryke reeks tekste gepubliseer waarin 'n aantal herhalende temas na vore getree het, wat na die premisse van hierdie artikel nie saamgebundel sou kon word in 'n enkele metodologies-teoretiese program nie. Eerder het Foucault via dramatiese historiese analises, waarvan gedetailleerdheid, presisie, dog aweregse resepsie, die eerste kenmerke was, die gestandaardiseerde moderne perspektief op 'n hele aantal moderne institusies en, ten grondslag daarvan, fundamentele Westerse opvattinge rondom rasionaliteit, waarheid, mag, tegniek, etiek en geregtigheid, in kort die hele sosiaalwetenskaplike milieu van die 20ste eeu, geprovokeer.

Huiwerig dan om van 'n 'metode' by Foucault te praat, fokus hierdie artikel op aspekte in Foucault se stroom-op, modernkritiese historiografieë wat binne die konteks van die middelgedeelte van die groter oeuvre so prominent en herhalend is, dat dit minstens as tendensieuse konsepte in sy analises gekenmerk kan word. Die vraag is watter idees hierdie tendensieuse konsepte voed, hoe hierdie konsepte semanties en semiologies funksioneer en, by implikasie, hoe toepaslik hierdie konsepte sou kon wees as komplemente vir gestandaardiseerde, kwalitatiewe en induktiewe metodes soos teksanalise, waarneming, asook progressiewe historiese ondersoeke, in die sosiale wetenskappe.

Die beskrywing van 'n metodologie is inderdaad kontroversieel in die Foucault-navorsing: Moet Foucault gelees word as 'n onmetodologiese historiograaf wat juis nie in die modernistiese korset van 'n 'metode' en implisiet 'n 'teleologie' ingedwing wou word nie, of moet die herhalende, duidelik-isoleerbare aspekte van sy analises nie dui op metodiese kwaliteite in sy provokatiewe analises van onder meer waansin, dissipline, dissidentskap, kriminaliteit, geestessiekte, sanitasie, delirium, patologie, seksualiteit, 'goewermentaliteit' - en al die moderne institusies wat hierdie 'Ander' (Beukes 1996:233-235) in bedwang hou - en so meer nie? Sou die resepsie moes volstaan by hoogstens die stemming van Foucault se ondersoeke? ${ }^{1}$ Of sou hierdie herhalende kwaliteite

1.Foucault was op grond van ' $n$ 'skaarste aan ' $n$ koherente metodologie' nie verbaas daaroor dat moderniste sy werk 'as surrealisties (sou) kenmerk' nie (Foucault 1965:iii, Voorwoord). Op die direkte vraag in 'n onderhoud gedurende die middelfase van sy loopbaan, "Het Michel Foucault "n metode?', antwoord hy: "Ek het geen mo met ' $n$ "prestige van koherensie", anie ... nie; hoe meer nuwe, moontlike, onvo aste fase va loopbaan wat die jare 1978 to 1984 bestryk (Paras 2006.2, Beukes 2009b:9). Dit nooi sy leser uit' om sy analises geneaologies self verder te neem, of selfgenealogies verder te neem, met ' $n$ voortgaande 'versorging van die subjek', met ' $n$ klassieke Aristoteliaanse epimeleia heautou, besig te wees. Hierdie artikel wil meewerk om die bedding te beskryf waarin daardie 'kritiese ontologie van die Self' (Foucault 1984:47) as 'n logiese ontwikkeling in die oeuvre kon manifesteer. 
in sy werk wel as 'konsepte' gekenmerk kon word, sonder om van Foucault 'n moderne teleoloog te maak, of die middel-Foucault self te verkneg aan die parameters van sy eie 'metode'?

Daar is twee duidelik onderskeibare standpunte in hierdie verband: Die een standpunt is dat Foucault se ondersoeke so uniek, onherleibaar en onherhaalbaar is, dat enige herhaling daarvan of die omvorming daarvan tot 'metode' juis die hiperkontingente aansprake van Foucault se analises ontkragtig (kyk bv. Megill [1985:17], op grond van die 'Nietszcheaans-dionisiese karakter' van Foucault se projekte; Miller [1994:181], op grond van Foucault se aversie aan die 'metodies-dogmatiese indroktinasie van studente'; Paras [2006:2], op grond van die diskontinuïteit tussen die vroeë-, middel- en latere werke van Foucault, wat in sigself die opvatting 'n koherente metodologie ondergrawe.). Die ander standpunt is dat daar wel 'n duidelik aanwysbare 'Foucaultiaanse metode' is (kyk in besonder Kendall \& Wickham [1999:viii; 5-8], twee navorsers wat inderdaad baanbrekerswerk in Foucaultiaanse navorsingsmetodologie gelewer het) wat meer programmaties geformuleer kan word sonder dat die 'teenswoordig-historiese' integriteit van Foucault se analises noodwendig daarmee skade aangedoen word nie. Die outeur kies om op 'n middeweg en ter wille van onderklemtoon eerder van 'analitiese konsepte' as 'n 'metode' by Foucault te praat. Premissegewys aanvaar ons dan dat Foucault (veral 1970, 1972, maar ook later 1980, 1981a, 1981b) wel subtiele metodologiese uiteensettinge van sy ondersoeke gegee het, maar dat dit nie as 'n koherente verduideliking van 'n 'Foucaultiaanse metodologie' beskou kan word nie.

Hierdie artikel wil dus, by alle antisipeerbare teenwerping, die waagmoedige weg volg en Foucault wel sistematiseer in terme van duidelik-isoleerbare tendense in sy werk baie pertinent nie om ' $n$ 'metode' daar te stel nie, maar om analitiese konsepte in sy werk uit te wys wat aansluiting kan vind by 'n groter spektrum van sosiaal-wetenskaplike ondersoeke. Dit sal op 'n ernstige verlies aankom indien Foucault se hiperkontingente analises self werklik net as 'teenswoordig' verstaan sou word. Sy analises is akkuraat: daarom verdien dit analitiese aandag. ${ }^{2}$ Die artikel het ook die bedoeling om hierdie konsepte in Foucault se werk te dissemineer en toeganklik te stel vir navorsers wat nie spesialistoegang tot die oeuvre het nie. Die taalgebruik in die artikel is daarom bewustelik gestroop tot die kursoriese, huiwerig om Foucault se verleidelike prosa na te praat,

2.Te dikwels word Foucault binne ' $n$ 'post'-georiënteerde geselskap ingedwing wa vir hom wesenlik vreemd was: die sogenaamde 'post-strukturaliste' (kyk Beukes 2002b:994-996), of ' $\mathrm{n}$ meer algemene 'postmoderne dekonstruksie' (Beukes 2002a:283-286), terwyl Foucault self nooit die begrip 'postmodern' gebruik het nie en later in sy loopbaan baie ernstige voorbehoude oor die begrippe 'post/strukturalisties' gehad het (kyk Miller 1994:32, 81, 134-136; vgl. Paras 2006:30-35). Die begrip 'kritiek van die moderne' kom wel herhaldelik en 2006.30-35). Die begrip 'kritiek van die moderne' 'postmodern' nie. Foucault geaksentueerd in sy werk voor - maar nie die begrip 'postmodern' nie. Foucault was intens bewus wan ' 2005:1102, kyk Millor nie lat verlei om hom dien dat dit spoedig weer as 'n normaliserende, dissiplineringsmatige korset sou begin funksioneer - wat uiteindelik in terme van ' $n$ 'epistemologiese uitbranding van die postmoderne projek' (Beukes 2005:1102-1105) reeds gebeur het. hoewel Foucault self by verwysing aan die woord gestel sal word ter rugsteuning van die analitiese uiteensetting. ${ }^{3}$

Verder beperk die artikel sigself pertinent tot die middelfase van Foucault se loopbaan. Die bronnehantering in hierdie artikel sal dus grootliks tekste gepubliseer tussen 1962 en 1977 reflekteer. Met die verskyning van Eric Paras se uitnemende betragtingswerk, Foucault 2.0 (2006), het dit duidelik geword dat die navorsing groter agting behoort te toon vir die ontwikkeling in Foucault se oeuvre, in terme van drie aanduibare fases (Paras 2006:5-18): Die eerste fase in Foucault se werk was grootliks gemoeid met die filosofiesteoretiese grondslae van die psigiatrie in die laat 1950's, sowel as sy deelname aan die laat-eksistensialistiese, vroegstrukturalistiese debat in Frankryk in die eerste jare van die 1960's (vgl. Paras 2006:19-46). Meer oor hierdie eerste, strukturalisties-gedrewe fase volg later in die artikel. Die tweede fase in Foucault se oeuvre dui aan wat die outeur benoem as die 'teenswoordig-historiese Foucault', of titelgewys dan 'middel-Foucault', 'n fase wat oorwegend gekenmerk word deur Foucault se unieke argeologiese en genealogiese analises van moderne institusies. Hierdie fase sluit Foucault se werk vanaf 1962 (die verskyning van Madness and Civilization in Frans) tot en met 1977 (die verskyning van die eerste volume van The History of Sexuality in Frans) in. Die derde fase bestryk die periode vanaf 1978 met die verskyning van die tweede volume van The History of Sexuality in Frans, sy berugte joernalistieke ekspedisie na Iran tydens die Iranese revolusie vanaf September 1978 tot Mei 1979 (Beukes 2009a, 2009b) en die publikasies wat daaruit voortgekom het. Dit sluit ook in die uiteindelike publikasie van sy lesings by die Collège de France vanaf die vroeg 1980's, wat ook die wesenlike inhoud van sy lesings by Buffalo en Berkeley in die VSA (kyk Foucault 1971:72-73) tot net voor sy afsterwe in 1984 bepaal het, en wat uiteindelik behoorlik gesistematiseer, getematiseer en gekommentarieer is deur Paras (2006).

Paras (2006:1-15) verantwoord die faseologie van 'n vroegna middel- na laat-Foucault baie duidelik en geloofwaardig. Daarom word die legitimiteit van sy indeling sonder 'n verdere kritiese analise aanvaar. Die aanduiding van sodanige periodisering van Foucault is egter vars in die navorsing en tot op datum betreklik ondergepubliseerd. Hierdie artikel werk tot ' $n$ bydrae in daardie meer gespesialiseerde, intrarefleksiewe deel van die Foucault-navorsing mee. Hoe hierdie drie aanduibare fases in Foucault se oeuvre tematies met mekaar skakel, sou die onderwerp van 'n afsonderlike studie moes wees en sal nie hier aandag geniet nie.

Die oortuiging wat die impetus voorsien het aan middelFoucaultiaanse analitiese konsepte soos argeologie,

3.Dit spreek vanself dat hierdie artikel nie as'n omvattende inleiding kan dien tot die algemene kenmerke van Foucault se intellektuele erfenis nie. Daar is vandag, 27 jaar na sy dood, meer as genoeg inleidings en bloemlesings in die handel beskikbaar. spesifiek die Afrikaanse taal, sien Beukes (1996, 2002a, 2004, 2008). Daar sal in hierdie artikel ook verwysingsmatig gebruik gemaak word van die talle onderhoude wat Foucault in hierdie middelperiode toegestaan het en wat later geredigeer en gepubliseer is, in besonder in die uitstaande redaksiewerke van Lotringer (1996) en Kritzman (1990). Let daarop dat verwysings na Foucault se werk in die teks die datums van die vertalings daarvan aandui, ter wille van lesers wat Frans nie magtig is nie en die verwysings sou wou kontroleer en wyer sou wou kontekstualiseer. 
genealogie en diskoers, naamlik teenswoordige geskiedenis, sal aangedui en bespreek word as die leitmotiv in die middelfase van Foucault se werk, in die sin dat teenswoordige geskiedenis Foucault se ander historiografiese en sosiodiagnostiese konsepte vanuit die middelperiode ondervang of bemoontlik. Hierdie ander konsepte, naamlik argeologie, genealogie, diskoers en daarby ingeslote magsanalise, word vervolgens sistematies bespreek en hulle onderlinge samehang verduidelik. Die aksent val egter op argeologie en genealogie, nie bloot omdat dit die temas is wat die skerpste herhaal word in die middeldeel van die oeuvre nie, maar ook omdat dit die middeldeel van die oeuvre self weer in twee duidelike fases periodiseer.

\section{Teenswoordige geskiedenis}

Die opvatting van 'n versteurde, genormaliseerde, gedissiplineerde of dosiele subjek staan sentraal in middelFoucault se analises en sy opvatting van teenswoordige geskiedenis. Foucault (1972:4) se sentrale vraag binne die konteks van sosiale wetenskapsbeoefening verskil aanvanklik nie wesenlik van die veel ouer, 19de eeuse Diltheyaanse vraag nie: Hoe is sosiaal-wetenskaplike (of skerper Diets, 'geesteswetenskaplike') kennis hoegenaamd moontlik? Hoe word oor die mens as intrinsiek sosiale wese en die mensheid as voortgaande sosio-historiese gebeure kennis verwerf? Wat is dus die hermeneutiese voorwaardes vir sosiale kennis en wat bemoontlik die sosiale diskoers op enige gegewe stadium van die geskiedenis? Hoe word (deur subjekte) wetenskaplik oor die subjek gepraat? Waarom, vir Foucault, word in die moderne sosiale diskoers by voorkeur met premisses van onverstoordheid, kontinuiteit, universaliteit en identiteitstigting gewerk, ook juis binne die konteks van ernsname met die vraag na die moderne dissident: die waansinnige, die parafusin, die delinquent, die homoseksueel, die Orientale, die Ander? Foucault (1969a:52) se diepste indruk oor die sosiale wetenskappe is juis dat hierdie wetenskappe nie met onverstoorde of heel subjekte as objekte van ondersoek werk nie, maar met altydreeds geaffekteerde, genormaliseerde en diep versteurde subjekte, wat as sodanig binne hulle eie kontingente en genormaliseerde historisiteit en institusionaliteit verstaan moet word. ${ }^{4}$ Hierdie indruk is die vernaamste geleier vir Foucault se opvatting van teenswoordige geskiedenis.

Sosiale ondersoeke loop volgens Foucault die radikale, misplasende risiko om bewussynsvelde te vernou wanneer

\footnotetext{
4.Subjektiwiteit is by Foucault deurgaans eerder' $n$ wispelteurige sosiale konstruksie as'n nominaal-stabiele gegewe, soos die transendentale Self by Rousseau en Kant, die ego in Freudiaanse psigoanalise of operatiewe intensionaliteit in Husserliaanse fenomenologie: daar ontbreek volgens Foucault by subjekte enige fakulteit vir 'n fenomenologie: daar ontbreek volgens Foucault by subjekte enige fakulteit vir ' $n$
onveranderlike, vasstelbare norm of statuut vir subjektiwiteit (vgl. Dosse 1997:4). onveranderlike, vasstelbare norm of statuut vir subjektiwiteit (vgl. Dosse 1997:4). historiese norme en statute wat gedefinieer word deur die praktyke en institusie waarbinne subjekte gevorm word. Daarom is subjektiwiteit by Foucault beide histories-kontingent en institusioneel. Dit beteken dat die subjek ondersoek moet word in terme van die histories-kontingente kwaliteite van die subjek, waarvoo institusionele gebedheid ' $n$ wesenlike geleier is. Daar is dus nie iets soos die subjek by Foucault nie, eerder skerp partikulariserend alleen maar ' $n$ subjek gebed in ' $n$ bepaalde sosio-histories-institusionele praktyk (vgl. Miller 1994:69). Dit is ' radikaal beskeie visie van die moderne subjek, indien nie volledig desentraliserend radika nie, gegewe die programmatiese grandeur van betreklik jong moderne dissiplines soos psigiatrie en, nog jonger, psigologie en kriminologie (Foucault 1976:196) Dit sou, polemies gesproke, vir Foucault onmoontlik wees om byvoorbeeld ' gestandaardiseerde sielkundehandboek of kriminologiehandboek te lees sonder om te gryns (vgl. Foucault 1976:197). Indien daar na Foucault wel iets soos 'waansin' of 'kriminaliteit' is, is ons almal ietwat waansinnig of krimineel, synde almal versteurd, genormaliseerd of dosiel (vgl. Beukes 2009a:4; Paras 2006:69).
}

outoriteit ten aansien van die subjek deur objektiverende rasionaliteit toegeëien word, in stede van die bewustelike en kritiese herkenning van die versteurde subjek, wat per definisie aanwesig is in elke sosiale teorie en uitspraak. Moderne sosiale diskoerse kies volgens Foucault bykans sonder uitsondering vir die bevestiging van die outoriteit van 'n stabiele subjek - gedra deur begrippe soos die identiteit, die groep, die norm, die ruimte, die redelikheid, die morele kwaliteit - eerder as wat die versteurdheid van subjekte in ' $n$ lewende, deelnemende gemeenskap ondersoek word. Foucault vertoon 'n onbehae in bepaalde lidwoorde en wil gedurende die middelfase van sy loopbaan die sosiale versteurdheid van juis ' $n$ subjek teenswoordig-histories ondersoek.

Die - of eerder ' $n$ - versteurde subjek neem Foucault se argeologiese en genealogiese projekte ${ }^{5}$ na die sentrum van sosiale ondersoek, in die sin dat dit die moontlikheid van sosiaal-wetenskaplike kennis as 'n kennisvorm wat binne die kontingensie van die historiese en institusionele proses gevorm word, wil oorweeg (Foucault 1977a:145). Sosiale diskoers tree binne bepaalde historiese tydsgewrigte na vore, na gelang van die kennisstrukture of epistemiese strukture wat sosiale postulate op daardie stadium moontlik gemaak het (oftewel die argeologie van sosiale kennis). Sosiale diskoers tree volgens Foucault ook na vore in die verhouding tussen subjekte en institusies en die wyse waarop hierdie verhouding tussen subjek en institusie die diskoers self bepaal (oftewel die genealogie van sosiale kennis). Dit beteken dat begrippe soos redelikheid, waarheid, etiek en geregtigheid gevorm word deur die dominante kennisvorme - of regimes van kennis - wat beskikbaar was op 'n bepaalde stadium van die geskiedenis en argeologies ontlaag moet word. Dit beteken uiteindelik ook dat die institusionalisering van redelikheid, etiek en geregtigheid genealogies teruggevind moet word.

Sosiale kennis wil immers 'die waarheid oor die/'n subjek praat', met inbegrip van die waardes, voorwaardes en belange van die bepaalde tyd - en juis in die of ' $n$ bepaalde gemeenskap. Tog sou 'n mens na Foucault kon beweer dat 'geskiedenis' in die moderne diskoers 'n verbeelde ruimte behels waarin die politiek-teenswoordige bestendig word, 'n verbeelde ruimte waarin die verlede as't ware kwytgeskeld

5.Voorlopig kan gestel word dat Foucault se middelfase kennisleer vanuit die konsepte 'argeologie' en 'genealogie' vertrek, wat self weer op die opvatting van teenswoordige geskiedenis terugval. Argeologie wil poog om in terme van 'woorde en dinge' die waarheidstigtende elemente in 'n diskoers te identifiseer, waarom dit en dinge' die waarheidstigtende elemente in ' $n$ diskoers te identifiseer, waarom dit as 'kennis' (dus as 'waar', 'redelik', of selfs 'eties') sou geld. Genealogie (vgl. Foucault
1977a:145-146) wil verder gaan en in terme van magsanalise die oorspronge van hierdie diskoerse identifiseer, hoé diskoerse dus gevorm word, maar veral, waarom diskoerse institusie-histories varieer. Die spanningsvolle korrelasie van waarom diskoerse institusie-histories varieer. Die spanningsvolle korrelasie van
kennis met ' $n$ eietydse kultuur is vir Foucault van deurslaggewende belang in die vorming van die Westerse intellektuele tradisie. Foucault speel dus op hierdie blywende probleem in die eietydse gedaante daarvan in, wanneer hy argeologies en genealogies sistematiese vrae oor die aard en aansprake van tradisie, ruimte, outoriteit en mag in die sosiale wetenskappe stel. In besonder die middelfase van sy werk moet daarom teen die agtergrond van die steeds-ontwikkelende geskiedenis van die Westerse intellektuele tradisie verstaan word, veral ten opsigte van sy analise van die kulturele waardes van moderne institusies: Dit is ' $n$ analise wat die wetenskap terug in die geskiedenis bring ' $n$ analise wat die grondslae van sosiaal-wetenskaplike kennis - gegewe dus die stand van kultuur en kennis vandag sosiaal-wetenskaplike kennis - gegewe dus die stand van kultuur en kennis vandag - telkens herondersoek. Hierdie insig in die historisering en institusionalisering van sosiale kennis, gegewe die modernkritiese stemming in die eietydse filosofie, skep 'n noodsaaklike spanning in die verhouding tussen kultuur en wetenskap (kyk Caputo \& Yont 1993.25, vgl. Rogerson 2000:37). Dit is nie net religie wat sigself teen sekularisasie moet verweer nie: die gesekulariseerde kultuur self sal dit moet doen, ten einde nie onder te gaan in 'n laaste Nietzscheaanse Stundes meines Niederganges, Unterganges nie. 
word van die plig om die waarheid van die teenswoordige te wees. Dit sou ook anders gesê kon word: Wanneer sosiale wetenskap in eietydse gedaante teenswoordige geskiedenis herken, erken dit ineens ook die feit dat enige beroep op die verlede, paradoksaal, ' $n$ bevestiging is van die huidige politieke begeerte na kennis en mag aangaande die aard van 'waarheid'. Indien sosiale wetenskap die argaïese preservering van hierdie telkens (her)verbeelde verlede te bowe sou wou kom, sou sosiale wetenskap dus bereid moes wees om telkens die inhoud en aansprake van die eie tradisie in die nuwe ruimtes van ' $n$ eietydse wêreld sonder vrees of vooroordeel te onderhandel.

Hoe sou die hermeneutiek van só 'n sosiale wetenskap lyk? Dadelik sou 'n mens moes sê dat die taak van so 'n hermeneutiek gerig sou moes wees op die ontmaskering van die ideologiese distorsie in (of die sosio-historiese geladenheid van) 'n bepaalde wetenskaplike of intellektuele tradisie. Foucault (1977a:29) dring daarop aan dat dít wat ons probeer verstaan, voortdurend en sistematies besig is om die bindinge daarvan met mag en onderwerping te konfigureer as iets anders, oftewel dat ons in die verstaansproses mislei word deur die konfigurering of maskering van mag. Foucault toon aan dat alle kennisvorme sosio-historiese- en tradisiegebonde gegewes is wat die werklikheid nie kan begryp 'soos wat dit is' nie. Kennisvorme is na Foucault se mening, in noue aansluiting by Gadamer, altyd besig om vanuit ' $n$ bepaalde sosio-historiese raamwerk of 'tradisie' deel te neem aan die werklikheid en is self besig om te skep of te interpreteer, eerder as wat kennisvorme as ontdekkend of dokumenterend van aard beskou kan word. Foucault beskou juis daarom denkkategorieë wat verwyderd is van die praktyke van 'n eietydse, lewende, deelnemende gemeenskap as die 'groot illusie van die sosiale wetenskappe' (Foucault 1977a:30).

Die sosiale wetenskappe, sou 'n mens ook kon sê, is dus voortdurend in 'n stryd gewikkel tussen die waardes van 'n intellektuele tradisiebewaring en tradisie-interpretasie. Indien die sosiale wetenskappe dit sou wou vermy om met ' $n$ gewaande opwaartse kurwe bloot 'n teleologiese ensiklopedie van die 'prestasies van die verlede' of 'n vergeestelikte model van 'n wetenskaplik-positivistiese ortodoksie te verteenwoordig, sou die sosiale wetenskappe bereid moes wees om telkens die teenswoordige geskiedenis as voorwaarde vir sosiale kennis en die ontmaskering van die politiek van wetenskaplike denke te verken. Foucault se konseptuele raamwerk verskaf juis die geleentheid om hierdie teenswoordig-historiese voorwaardes vir sosiaalwetenskaplike kennis te ondersoek. In hierdie ondersoek sou dit moontlik word om die ideologiese distorsies in die wetenskap self te identifiseer en die verskuilde regimes van mag onderliggend aan die baie deugde van die wetenskap, uit te wys en voortdurend verder te verken.

Indien die versteurdheid van die subjek die stemming van 'n teenswoordige geskiedenis bepaal, is die volgende vraag wat die analitiese kenmerke van hierdie middel-
Foucaultiaanse werksbegrip is. Die tweede kenmerk van 'n teenswoordige geskiedenis is naamlik dat daar vir Foucault geen grense aan die diagnostiese gebruik van die geskiedenis gestel kan word nie. Foucault gebruik geskiedenis as die eerste en vernaamste tegniek om sy analises van waansin, seksualiteit, dissiplinering, die subjek, die liggaam en so meer gestalte te gee. So word sy geskiedenis van waansin, byvoorbeeld, 'n kommentaar op die stand van eietydse rasionaliteit, redelikheid en orde. Dit is vir Foucault nie moontlik om a-histories oor die werklikhede wat hy deurvors te praat nie, ook nie in terme van die hede of die toekoms nie. Foucault se geskiedenisse eindig met ander woorde nooit nie: dit is volledig onteleologies, met geen implisiete verlossingspretensie nie. Of Foucault (1978:42) nou simplistiese kategoriserings van seksualiteit in die Victoriaanse epog as 'teruggetrokke' problematiseer en of hy waansin as 'n statiese diagnostiese kategorie, as 'n aanbod van prognose-ontwikkeling, in die moderne psigiatrie problematiseer (Foucault 1965:105 e.v.) - hy maak geen aanspraak op vordering of progressie deur die geskiedenis heen nie; trouens, die enigste aanspraak wat hy maak, is dat geen vordering gemaak is nie en dat die kontingente aan die historiese werklikheid binne die hede gerespekteer moet word. Daarom word die geskiedenis nie halt geroep nie: dit moet juis in die teenswoordige nawerking geniet.

Foucault se middelfase geskiedenisse is teenswoordige geskiedenisse, nie om vas te stel hoe die teenswoordige vanuit die historiese ontwikkel het nie, maar juis om die historiese te gebruik om die teenswoordige te diagnoseer. As analitiese konsep wil teenswoordige geskiedenis nie domeine van nuwe verstaanbaarheid oprig nie, maar juis die historiesonverstaanbare en histories-onredelike in hermeneutiese spel bring. Teenswoordige geskiedenis wil dus nie meewerk tot gemak met die hede nie, maar die hede juis problematiseer vanuit die verlede. Dit wil die hede versteur omdat die subjek blywend versteurd is: 21ste eeuse benaderings tot seksualiteit byvoorbeeld, is nie minder problematies as 19de eeuse Victoriaanse benaderings nie, en 21ste eeuse diagnoses van waansin self nie minder problematies as die 19de eeuse voorgangers daarvan nie - dit is een en dieselfde konstellasie van mag en kennis wat die begrip dra en dit is een en dieselfde subjek wat steeds daardeur versteur word. Maar 19de eeuse Victoriaanse benaderings werp juis lig op 21ste eeuse benaderings tot verskynsels soos seks(ualiteit) en waansin, omdat dieselfde versteurde subjek daarin werksaam is.

'n Derde kenmerk van teenswoordige geskiedenis is dat dit skerp op die kontingente fokus - en nie op oorsaaklikheid nie. Foucault fokus gedurende die middelfase van sy werk ironies konstant op kans, spontaniteit, terloopse insidente en nie op 'n kousaliteit wat meewerk tot die opwaartse kurwe van 'n modern-teleologiese historisme nie. Foucault fokus by voorkeur op daardie insidente in die geskiedenis wat nie noodsaaklik was of noodsaaklikerwys veroorsaak is nie; dat die betrokke insident bloot een moontlike gevolg vanuit 'n radikaal onordelike sisteem van komplekse verhoudinge, gebeure, netwerke en interaksies was - 'n 
fantasties onbedoelde aansluiting by die beste insigte vanuit die 21ste eeuse teoretiese fisika. Foucaultiaanse kontingensie beteken nie dat enige iets uit daardie onordelike sisteem kon voortkom nie, maar bloot dat dit wat wel daaruit voortgekom het, binne die netwerk self deur kans bevoordeel is, byvoorbeeld, deur onverbonde veranderinge in ander elemente in die sisteem, analoog aan Weber se oorbekende 'paradoks van die onbedoelde gevolge van die geskiedenis', of Deleuze en Guattari (1987:3-25) se 'risoom', waar die boom van kennis van goed en kwaad nie een is waarvan die takke betreklik voorspelbaar na bo uitwaarts groei en die wortels dieper delf nie, maar eenvoudig 'n tak- en wortelstelsel wat deurmekaar groei en selfs inmekaar groei. Elke kontingente is in kontingente verhouding met elke ander kontingente. Daar is dus geen patroon vir kousale relasie nie.

Vierdens is ' $n$ teenswoordige geskiedenis radikaal skepties, of anders gesê, dit is bereid tot die opskort van tweede-orde (of politieke, of publiekgestelde, oordele). Hiermee word bedoel dat alle oordele wat nie herken word as eie (dit is eerste-orde) oordele nie, opgeskort moet word. Hoewel dit hermeneuties 'n uitdagende opgawe is, of aanvanklik inderdaad betreklik kontra-hermeneuties is (Paras 2006:54), is dit nie geslaagdheid van die poging tot die opskort van tweedeoordele wat tersake is nie, maar eerder die selfonderbrekende, subjekverposende proses wat hierdie poging ondervang. Die proses waarin gepoog word om tweede-oordele te identifiseer en voorlopig op te skort, lê aan die hart van die opvatting van teenswoordige geskiedenis en Foucaultiaanse historiografie in die algemeen (Rabinow 1984:375-376; kyk Foucault 1969b:58). Wanneer enige objek van ondersoek met 'n status beklee word waarvan die outoriteit ontleen is aan ' $n$ ander, afsonderlike, reeds publieke ondersoek, is dit 'n tweede-orde oordeel. ' $n$ Teenswoordige geskiedenis is in verset hierteen, omdat dit toegeeflik staan teenoor die moontlikheid van a-historiese perspektiewe wat in hermeneutiese spel gebring word - terwyl die opvatting van teenswoordige geskiedenis die moontlikheid van a-historiese refleksie skerp teenstaan.

Foucault se analise van ars erotica in antieke kulture (Foucault 1978 [in 1977 in Frans gepubliseer], kyk Beukes 2002a) verskaf 'n goeie voorbeeld van die wyse waarop die opskorting van tweede-orde oordele as 'n tipies middelfase projek in Foucault se oeuvre funksioneer. Bykans tweehonderd jaar ná De Sade se Verligtingskritiese Juliette, word die Westerse wêreld in Foucault $(1978,1985,1986)$ se epogmakende en deels postuum trilogie, The History of Sexuality I-III, vir die eerste keer met 'n werklik seminale analise van seksualiteit gekonfronteer, wat nie op die geykte moderne, psigoanalitiese stereotipes van repressie en emansipasie terugval nie. Die leidingsvraag is: Hoe het seks 'seksualiteit' geword (vgl. Foucault 1977c:212)? En daarmee saam:

Hoe het dit gebeur dat seksualiteit die bevoorregte ruimte geword het waar Westerlinge se identiteit tot uitdrukking gebring word - waarom nie meer slegs prokreasie of slegs erotiese plesier nie; waarom diskoers? (Foucault 1977d:214)

'Vertel my jou begeertes en ek vertel jou wie jy is - die stelling is tipies van die $19 \mathrm{de}$ eeu en alles wat daarop sou volg' (Foucault 1990a:11).
Foucault poog in bogenoemde trilogie om die algemene opvatting dat die Westerse samelewing 'n onderdrukking van seksualiteit sedert die $17 \mathrm{de}$ eeu beleef het, vanuit ' $n$ teenswoordig-historiese analise binne kritiese perspektief te stel. Die gangbare opvatting, selfs tot so onlangs as in die 1960's, was dat seksualiteit sedert die 17de eeu, veral in die Victoriaanse periode, onderdruk en gemarginaliseer is en dat dit daarom nie moontlik is om enige wesenlike uitsprake te maak oor die seksualiteitsbeskouing van die periode vanaf die 17de eeu tot diep in die 20ste eeu nie, omdat seksualiteit na hierdie opvatting eers 'diskoers' ('n middelfase konsep waarby ons later deeglik vertoef) sou word met die afloop van die kultuurrevolusie van die 1960's. In die vroeg 1970's, toe Foucault aan die eerste volume begin skryf het, was die seksuele revolusie van die 1960's grootliks reeds voltrek. Tipies seksueel-populistiese opvattinge vanuit hierdie periode, wat vandag betreklik studentikoos aandoen, soos dié van die psigoanalis Wilhelm Reich, wat geleer het dat mentale gesondheid regstreeks korrespondeer met die bevryding en vrystelling van seksuele energie, is deur 'n hele geslag as normatief aanvaar, terwyl die verlede - juis op sterkte van a-historiese, tweede-orde oordele (vgl. Foucault 1975b:155) - toenemend beskou is as 'n duister tyd waar die seksuele diskoers verbode was.

Foucault wys hierdie a-historiese beskouing van seks/ ualiteit as foutief uit. Foucault dui naamlik aan dat die Westerse samelewing sistematies en wetenskaplik gefikseer het op seks, seksdade, seksmiddele, seksvoorwaardes, en so meer: byvoorbeeld, die 'vagina' wat vrouens 'het', wat hulle met hulle liggame seksueel 'doen', met skerp anatomiese blik op aspekte van vaginaal-seksuele funksies, soos die onderskeid tussen die klitoriese en vaginale orgasme ('n absoluut ondenkbare diskoers in die vroeg 20ste en enige voorafgaande eeu). Die vagina en haar seksuele funksies word vanaf die 1950's via tipiese studieprojekte van die laat-moderne, soos die Kinsey-projek, toenemend publiek en word 'n fokus van ondersoek, konstante waarneming, daarom normaliserend en konstant onderworpe aan eksaminering, gemaak. Nou word dit byvoorbeeld moontlik om, gekamoefleer as 'kunde', triviaal-ginekologies en progressief publiekstellend oor die 'vagina' te praat - en nou, in 'n beroemde uitspraak van Foucault (1977a:230; kyk Foucault 1969a:56), is 'elkeen en almal 'n ginekoloog'. Dit het 'n 'tweede-orde vagina' geword, sou Foucault (vgl. 1975b:163) beweer - 'n anatomies-fisiologiese werklikheid wat nou sosiaal-seksuele intervensie aanmoedig. Ginekologies kan die vagina uiteraard ondersoek word: maar nie sosiaal nie. Juis wanneer die anatomiese ondersoek aanspraak sou maak op sosiaal-wetenskaplike kennis, is daar ernstige teenwerping vanaf Foucault: Dit word dan onder meer ' $n$ 'histerisering en psigiatrisering' van vroulike liggaamlikheid (Foucault 1977c:213). Die anatomiese ondersoek het geen binding met die werklikheid van 'n partikuliere vrou wat worstel met die werklikheid van haar partikuliere brose liggaamlikheid of seksuele (dis)funksie nie - haar liggaam het in die moderne periode gewoon 'n publiekgestelde, wetenskaplike konvensie geword. Die potsierlike voorblaaie van sogenaamde vrouetydskrifte en, aan die ander kant van 
die fatsoenlikheidspektrum, pornografiese ${ }^{6}$ hiperbole van die vagina, het van hierdie versteuring in die laat-moderne periode 'n duidelike reklamebord geword: vandaar die 'Westerse seksuele droefheid' (Foucault 1977d:215), wat nie deur enige intensifisering van erotiese plesier opgehef kan word nie (vgl. Foucault 1977c:207).

Die Middeleeuse en vroeg-moderne sosiale konvensies wat nie-prokreatiewe seks verbied het, het juis 'n diskoers ten opsigte van moderne 'seksualiteit' tot stand gebring, op grond waarvan moderne 'seksualiteit' 'n openbare ordening van dissipline, normalisering en tegniek ten opsigte van die seksuele kondisie geword het. Die moderne konsep 'seksualiteit' is self 'n resultaat van hierdie diskoers en daarom is moderne 'seksualiteit' volgens Foucault'n betreklik resente uitvinding. Foucault vind die primêre openbare ruimte waarin moderne 'seksualiteit' diskoers geword het, juis terug in 'n publiekstellende oordeel van die allerhoogste tweede orde, met al die a-historiese outoriteit wat daardeur vooronderstel en ondervang is, naamlik die Katolieke biegpraktyk, vanwaar hy beweeg na 'n analise van die $17 \mathrm{de}$ eeuse, progressiewe verwetenskapliking van seksualiteit as scientia sexualis, die antipode van ars erotica, wat met geen minder openbaarmakende outoriteit met die klandestiene en privatistiese kwaliteite van seks, meer spesifiek speelse fornikasie en nie-prokreatiewe presentasies in terme van die orale en anale, wou afreken as eersgenoemde biegpraktyk nie. Dit is 'n buitengewoon uitdagende postulering: wat so eendimensioneel te siene is in ' $n$ harde pornografiese tydskrif of film, se diskursiewe voorganger is dit wat vanaf die 12de eeu gebeur het in die ewe eendimensionele priesterlike bieghokkie - beide is publiekstellend, enigsins sielloos, ingeslote en afgeruim, en beide het ekonomiese quid pro quo korrelate.

In hierdie breedvoerige analise van die middel-Foucault is daar geen spoor van ' $n$ tweede-orde oordeel nie - wel die pertinente identifisering van tweede-orde oordele. Foucault val in sy analise met ander woorde nie terug op bestaande opvattinge rakende antieke seksualiteit, die bieg of Victoriaanse puritisme nie - ongeag hoe akkuraat daardie opvattinge plek-plek ook al mag wees - maar skort dit op ten einde 'n teenswoordige geskiedenis van seksualiteit te kan skryf, waarin dus geen a-historiese aansprake gemaak word nie, en waarin dit duidelik blyk dat die mate van vergissings oor die liggaam, pornografiese mites en gekommersialiseerde hiperbole rakende seksualiteit in die laat 20ste eeu, nie minder skadelik en disorienterend is as enige voorgangers soos die bieg of scientia sexualis nie. Die kontemporêre subjek is immers nie minder versteurd as enige subjek in die vergange tyd nie.

Krities bewus van die priviligering van 'n kontinuïteitsopvatting ten aansien van die publieke, die rasionele, die sistematiseerbare en die gestruktureerde in die moderne, fokus 'n teenswoordige geskiedenis vyfdens op die modernkritiese rehabilitering van die Ander daarvan; die

6.Foucault se aversie aan pornografie is goed gedokumenteer: kyk byvoorbeeld Miller (1994:238) en Foucault (1990a:112).
oopskryfvanditwatstilgemaakis.Ditisdiegemarginaliseerde, versweë, vergete en verlore momente in die geskiedenis: die geskiedenis van waansin en nie redelikheid nie (maar juis om teenswoordig-histories oor redelikheid te kan praat), die geskiedenis van die behandeling van die liggaam (maar juis om teenswoordig-histories oor die 'siel', en dan uiteraard nie in Platoniese terme nie, te kan praat), die geskiedenis van stil erotika (maar juis om teenswoordig oor die kommersiële publiekstelling of andersyds die verwetenskapliking van die seksuele handeling, of gewoon fornikasie, te kan praat), en so meer. 'Ek wil die kultuur verstaan aan die hand van rituele van uitsluiting, daardie stelsels van ostrasering, verwerping, verswyging - kom ons noem dit dan die repressie-supressie stelsel' (Foucault 1971:69).

Vir die oopskryf van die stiltes van die Ander, is daar volgens Foucault drie voorwaardes, wat behoort te fokus op juis dit wat die kontinuïteit en priviligering in die eerste plek bemoontlik het, naamlik die kritiese rekenskap van tradisie, invloed en 'gees' (Foucault 1972:6-20). Die eerste voorwaarde vir die oopskryf van die stiltes van Ander in 'n teenswoordige geskiedenis, is die kritiese herkenning van die identiteitstigtende, uitsluitende en kontinuiteitsbestendigende dinamika van tradisie. Met tradisie word bedoel dat 'n spesiale tydelike status aan 'n groep verskynsels toegeken word wat sowel opeenvolgend as identies van aard is (Foucault 1972:12). Tradisie maak dit moontlik om a-histories te kan dink, juis met 'n beroep op die tradisie: refleksie oor die geskiedenis word so baie maklik bloot herdenking van die geskiedenis, die ontknoping van die geskiedenis word verstaan as gegiet in die voeg en vorm van homogeniteit en identiteit, dinge wat dieselfde is, terwyl die dinge wat skerp heterogeen en Anders is, noodsaaklikerwys uitgesluit word. Tradisie bemoontlik so 'n reduksie van die differensie wat aanwesig is in elke nuwe begin, ten gunste van die onversteurde, kontinuïteitsoekende beweging na die eerste oorsprong van die Self.

Die kritiese rekenskap van die opvatting van invloed is 'n tweede voorwaarde vir die oopskryf van die stiltes van die Ander: met invloed word bedoel die onkritiese rugsteuning en selfs verering van 'n veronderstelde stabiliteit van oordrag en kommunikasie, wat na 'n oënskynlik kousale proses verwys, wat op 'n afstand en deur tyd die vergange en die teenswoordige noodsaaklikerwys knoop. Die opvatting van invloed maak dit nogeens moontlik om a-histories 'n groepering uiteenlopende, vergange verskynsels volgens een en dieselfde organiserende beginsel te organiseer, met skerp verbygaan van dit wat nie met daardie beginsel assimileerbaar is nie.

Derdens moet die opvatting van 'gees' in 'n oopskryf van die stiltes van die Ander verreken word, waarmee Foucault (1972:13-16) bedoel dat die sosio-historiese kragte wat pasklaar sinteses voorsien (of groeperings van kennis en bundels standpunte wat op genormaliseerde wyse aanvaar word voordat dit onderwerp is aan kritiese eksaminering, en waarvan die geldigheid natuurlikerwys aanvaar word), geproblematiseer moet word. In stede daarvan om aan 
hierdie 'gees' ongekwalifiseerde, spontane waarde toe te ken, is die taak van ' $n$ teenswoordige geskiedenis juis om die arbitrêre, terloopse en spontane kwaliteit van die nosie van 'gees' uit te wys. Die geskiedenis van 'gees' bestaan uit afgelope momente, niks meer en niks minder nie, wat in hulle kontingente afgelooptheid genader moet word. Daarbenewens moet ons hierdie groeperinge van 'gees' waarmee ons so vertroud geraak het, voortdurend bly bevraagteken.

'n Teenswoordige geskiedenis wil al drie hierdie vooreksistente vorme van kontinuïteit, hierdie sinteses wat voetstoots aanvaar word, suspendeer: tradisie, invloed en 'gees' word deur 'n teenswoordige geskiedenis as gevaarlik en as risikos bejeën. Natuurlik kan nie een van die drie permanent opgelos of verbygegaan word nie, maar dit moet in suspensie gebring word, ter wille van die toeligting van die Ander. Die rustige klaarheid waarmee hierdie sinteses aanvaar word, moet deur die altyd-reeds versteurde subjek opnuut versteur word.

Minstens die volgende kenmerke behoort vanuit bostaande bespreking as sentraal tot die middel-Foucaultiaanse opvatting van 'teenswoordige geskiedenis' aangemerk te word:

- In die sosiale wetenskappe word gewerk met altydreeds geaffekteerde, genormaliseerde en diep versteurde subjekte, wat binne hulle eie kontingente en genormaliseerde historisiteit en institusionaliteit verstaan moet word. Daar bestaan volgens Foucault in die sosiale wetenskappe metodologies en diskursief nie iets gelykblywends soos 'die subjek' nie.

- Sosiaal-wetenskaplike kennis is 'n kennisvorm wat binne die kontingensie van die historiese en institusionele proses gevorm is en verstaan moet word.

- Die hermeneutiese taak van ' $n$ teenswoordige geskiedenis is gerig op die ontmaskering van die ideologiese distorsie in of die sosio-historiese geladenheid van aansprake vanuit ' $n$ bepaalde sosiaal-wetenskaplike tradisie.

- Daar kan geen grense aan die diagnostiese gebruik van die geskiedenis gestel word nie: dit is nie moontlik om a-histories oor enige navorsingsaspek in die sosiale wetenskappe te praat nie, maar terselfdertyd is hierdie perspektief volledig onteleologies, met geen verlossingspretensie wat deur die relevante geskiedenis gerig word nie. Die historiese word dus gebruik om die teenswoordige onteleologies te diagnoseer.

- Teenswoordige geskiedenis fokus op kontingentes en nie oorsaaklikheid nie. Elke historiese kontingente is in histories-kontingente verhouding met elke ander historiese (en dus ook teenswoordige) kontingente.

- Teenswoordige geskiedenis konstitueer 'n hermeneutiese proses waarin gepoog word om tweede-orde oordele te identifiseer en te suspendeer.

- Teenswoordige geskiedenis skryf 'stiltes van die Ander' oop en is daarom sensitief vir die gemarginaliseerde, versweë, vergete en verlore momente in die geskiedenis, wat veroorsaak is deur die identiteitstigtende, uitsluitende en kontinuïteitsbestendigende dinamika van pasklaar sinteses wat op self-immuniserende wyse telkens oorgelewer en aanvaar word. Daarom wil teenswoordige geskiedenis reeds metodologies rekenskap gee van en in konfrontasie tree met die self-immuniserende opvattinge van tradisie, invloed en 'gees'.

Hierdie oorwegings verskaf die ruimte waarbinne Foucault sy skerper genuanseerde historiografiese en sosio-diagnostiese konsepte gedurende die middelfase van sy filosofiese projek sou ontwikkel: argeologie, genealogie, diskoers en daarby ingeslote magsanalise. Hierdie diagnostiese gereedskappe oriënteer sigself konstant aan dieopvatting van teenswoordige geskiedenis, maar word ook metodologies saamgebind deur die opvatting van teenswoordige geskiedenis. Argeologie, genealogie, diskoers en daarby ingeslote magsanalise, is die analitiese konsepte wat Foucault gebruik om sy hoogs unieke verstaan van 'orde' te bring in die hiperkontingente aard van die geskiedenis, en wat ons in staat stel om hierdie konsepte metodologies in die groter sosiaal-wetenskaplike praktyk te implementeer, met inbegrip van die werk wat gedoen is ook in die laaste fase vanaf 1978 tot 1984. Vervolgens word oorbeweeg na'n bespreking van elkeen van hierdie konsepte.

\section{Argeologie}

Foucault se prominentse werke gedurende die middelfase van sy loopbaan (1965, 1970, 1972, 1973, 1977b, 1978) provokeer gestandaardiseerde moderne opvattinge rakende psigiatrie, geneeskunde, dissiplinering en die sosiale wetenskappe, ten opsigte waarvan 'normaliteit', 'gesondheid' en 'kennis' onderskeidelik in die 'moderne periode' (vir Foucault [bv. 1967:30] grootliks vanaf die 1790's tot die 1950's) waargeneem, geklassifiseer en versprei is. In sy wendingspublikasie van 1962, wat 'n duidelike ontwikkeling vanaf en inderdaad 'n breuk met sy vroegste werke gedurende die laat 1950's aandui, Madness and Civilization: A History of Insanity in the Age of Reason (in 1965 in Engels beskikbaar gestel), bied Foucault 'n 'geskiedenis van waansin in die era van die rede' aan, op grond waarvan Foucault 'n radikale verdeling in Westerse refleksie rondom rasionaliteitsaansprake bemerk: Rondom die 1650's, gedurende die periode wat Foucault as 'klassiek' benoem en wat dan strek tot die 1790's, het 'n kenmerkend moderne proses van 'Groot Uitsluiting' (in Engels normaalweg vertaal as Great Divide) momentum begin kry, waar deviante (waansinniges in die besonder) in nuutontwerpte 'huise van waansin' ${ }^{7}$ uit die samelewing weggesny is, om grootliks na hulleself om te sien.

Foucault (1965:38 e.v.) kontrasteer hierdie uitsluitende hantering van waansinniges in afsonderlike huise met die ambivalente lotgevalle van waansinniges gedurende die latere Middeleeue: enersyds het waansinniges volledig deel uitgemaak van die sosiale werklikheid en die perspektief van waansinniges is trouens as waardevol geag - soos dikwels by Shakespeare se karakters wat eers 'die waarheid' insien of praat nadat hulle 'waansinnig' geword het. Trouens, soms 7.Vandaar die lelike Dietse woord 'malhuis', wat om die pejoratiewe kwaliteit daarvan vermy behoort te word: 'Mal' beteken 'sleg' vanuit die gelatiniseerde oorlewering. Maar dit beteken ook kwaadwillig. 
kon net waansinniges 'die waarheid' praat omdat hulle nie aan die konvensionele sosiale sanksies van kontrole en beheer onderworpe was nie. Daarom was'n waansinnige'n welkome gas by enige adelike banket - langs die satiriese harlekyn of jester staan die waansinnige as eregas van 'die waarheid', wat die monarg na willekeur en sonder strafvooruitsig kon opponeer. Andersyds rekonstrueer Foucault (1965: 85-117) die laat-Middeleeuse opvatting van waansin via die esteties-hallusinerende sketse van Peter Bruegel en Matthias Grünewald, asook die karikature in Desiderius Erasmus se Verheerliking van waansin, waar waansin as sonde voorgestel word, 'n skandalige alternatief tot die rede, wat gevrees moet word. Die aanvanklike spontane Middeleeuse dialoog met en sosiale insluiting van waansin word so uiteindelik getermineer in die laat-Middeleeuse pleidooi om die radikale uitsluiting van waansin op grond van die teologiese nosies van sonde en gevallenheid - en dit, volgens Foucault (1977d:216), is die wegbereiding tot die patologisering van waansin in die moderne periode.

Die objektiewe korrelaat van hierdie konseptuele herstrukturering in die 'Groot Uitsluiting' is die 'Groot Gevangeskap' (in Engels normaalweg vertaal as Great Confinement) van die laat 17 de eeu: die abrupte internering van groot dele van die bevolking binne 'n nuwe georganiseerde netwerk van 'bewakingsinstitusies' deur die hele Europa heen. Die stigting van die Hôpital Général in Parys in 1656 was volgens Foucault (1965:55) in hierdie opsig 'n bakengebeure. Die Hôpital, anders as wat die naam 'hospitaal' na die eietydse betekenis daarvan aandui, was nie ' $n$ mediese instansie nie. Dit was 'n wegsluitplek, 'n samelewingskelder. Dit, saam met soortgelyke nuutgestigde vroeg-moderne instansies, het nie net waansinniges opgesluit en weggesluit nie. Ook skuldenaars, armlastiges, terminaal siekes, rondlopers, triviale misdadigers en politieke en religieuse dissidente is hierin weggesluit. Foucault (1965:98) beskryf met fyn ontleding en presisie die 'Groot Gevangeskap' as 'n morele paniek wat deur landelike verplasing, industrialisasie en 'n gevolglike surplus werkersklas veroorsaak is. Wat ook al die enkele rede, en die redes was waarskynlik meersinnig en dubbelsinnig - miljoene mense is weggesluit in hierdie 'bewakingsinstitusies', sonder enige uitweg.

An die einde van die 18de eeu het 'n ander wyse van die hantering van waansinniges, in opvolging van die 'Groot Uitsluiting' en 'Groot Gevangeskap', gestalte begin kry (Foucault 1965:159 e.v.). Die medisering van waansin word geprioritiseer en dokters en pasiënte word as 'n klas geskep. Psigiatriese kennis is binne 'n kort tydperk van ongeveer 25 jaar ontwikkel as 'n 'waansinskunde', op grond waarvan veral vier dinge plaasgevind het en wat met presisie deur Foucault (1965:150 e.v.) gedokumenteer word: die brein word afsonderlik tot die res van die liggaam geanatomiseer, waansin word 'n formele studieveld waarin (uiteraard nie-waansinnige) kundiges hulle loopbaangewys verdiep, waansin word 'n formele diagnostiese hoofkategorie (vir die eerste keer in die geskiedenis dus formeel 'n 'siekte', met 'n legio 'subsiektes') en die behandeling van waansinniges verskuif vanaf die huis van waansinniges en Hôpital na die kliniek, normaalweg 'n oop, landelike terrein, met vars lug, fraai tuine en pragtige argitektuur, wat op die oog af na 'n humanisering van die sosiale disposisie van waansinniges lyk.

In werklikheid is die moderne psigiatriese kliniek volgens Foucault (1965:241 e.v.) egter 'n 'enorme morele tronk'. Die brutale uitsluiting in huise van waansin en instansies soos die Hôpital, is vervang met 'n meer subtiele, intieme en selfsensurerende kontrolemiddel. Waansin word geskets as 'n morele gebrek, wat behandel moet word deur konstante waarneming en selfkorrigering, met aanspraak op die skuldbegrip en religieuse sentiment van die subjek. Die pasiënt, tussen die fraai tuine, word perpetueel beoordeel, subtiel gedreig en gekorrigeer. Die kliniek val terug op die karikatuur van die hegte gesin, waar die psigiater die paternalistiese rol van welmenende outoriteit oorneem. Die pasiënt internaliseer hierdie outoriteit, word meer konformerend en sosiaal minder vreemd, maar ook meer selfvervreemd en volgens Foucault by verre minder vry as die geboeide voorgangers in die brutale Hôpital.

Psigiatrie, as 'n eg-moderne dissipline, is volgens Foucault se middelfase analise korrup in terme van die prognostiese selfaanbod daarvan. Die mediese verstaan van waansin is 'n sosiale, moderne uitvinding, wat volledig deel uitmaak van die episteme of konseptuele skema van die betrokke periode. Sosiaal-wetenskaplike kennis in die algemeen, en psigiatriese praktyk in die besonder, kan volgens Foucault (vgl. 1990c:139-140) nie los verstaan word van ander moderne instituties wat die normalisering en dissiplinering van die subjek bevorder nie. Dieselfde soort argument word daarom voltrek in Foucault se The Birth of the Clinic (1973) en Discipline and Punish (1977b). Ook hierdie fyn dokumenterende en histories-analitiese werke handel oor 'n selfgekonstitueerde klas van kundiges wat, deur hulle taal en handelingspraktyke, waarheid en onwaarheid vasstel en daarmee subjektiwiteit nie beskryf nie, maar determineer. Waansin bestaan daarom slegs in die samelewing: 'Elke kultuur verdien sodoende die waansin wat dit toekom' (Foucault 1961:9).

Bogenoemde uiteensetting van die argumentatiewe trajek in Madness and Civilization is 'n goeie voorbeeld van die wyse waarop Foucault se argeologie as 'n middelfase-projek opereer. Maar hoe sien die teoretiese onderbou van hierdie Foucaultiaanse analise daaruit? Foucaultiaanse argeologie moet gekenmerk word as sou dit aanvanklik deel uitmaak van maar later in verset kom teen ' $n$ versameling WesEuropese reaksies wat in die laat 1950's en vroeg 1960's op 'n aantal 20ste eeuse teoretiese probleme na vore getree het, waarna losweg verwys kan word as 'strukturalisme', waarop feitlik dadelik met 'n 'post-strukturalisme' gereageer is, en wat oorhoofs as 'n filosofiese korrektief vir fenomenologie en eksistensialisme (Foucault 1969a:55) wou dien. Die Franse filosofie gedurende die 1960's kan terugskouend in twee duidelike fases onderskei word. Die eerste, strukturalisties- 
gedrewe fase, het ingrypende nuwe temas die tradisionele vraagarena van die filosofie binnegebring. Hiervan was (1) die kritiese bevraging van objektiwiteit, (2) die desentrering van die handelende subjek en (3) 'n selfkritiese of selfrefleksiewe poging om aan die tradisionele kennisaansprake van die filosofie te ontkom, die prominentste temas (vgl. Davidson 1997:1-3). Die bekendstelling van hierdie temas het egter steeds binne die veel ouer raamwerk van die Franse positivisme plaasgevind. In die tweede fase, wat óf beskou kan word as die aanvangsfase van post-strukturalisme óf as die laaste fase van strukturalisme (of dan, laatstrukturalisme), word die vernaamste aanspraak van die positivisme - die positiewe kenbaarheid van die werklikheid deur die objektivering en verwetenskapliking van die werklikheid - juis radikaal heraangespreek.

Die kritiese heraanspreke van die positivistiese agtergronde van die strukturalisme het tot ' $n$ verdieping in die verkenning van bogenoemde drie temas gelei (vgl. Paras 2006:19). Hierdie verdieping het uiteindelik die 'postmoderne toestand' in die latere werk van Lyotard, Deleuze, Foucault en ook Derrida filosofies gegrondves. Die feit dat strukturalisme en poststrukturalisme van mekaar onderskei kan word, beteken nie dat die twee liniêr of eendimensioneel uit mekaar gehou kan word nie. Daar was aanvanklik 'n mate van oorvleueling tussen hierdie twee rigtings, terwyl denkers se onderskeie posisies in die debat aanvanklik betreklik ongenuanseerd was. Dit geld veral vir Foucault, wat in die vroeë 1960's hom sonder skroom in die geselskap van strukturaliste soos Althusser, Barthes en Lévi-Strauss laat plaas het en hom dit selfs laat welgeval het (vgl. Eribon 1991:160-164), maar later radikaal afskeid geneem het van veral die Marxistiese ondertone van strukturalisme. Verder is dit moeilik om te onderskei tussen laat-strukturalisme en die aanvangsfase van post-strukturalisme, omdat die kritiek teen strukturalisme aanvanklik van binne die strukturalisme self (via Derrida en Lacan) gekom het (vgl. Paras 2006:19-45). Die beweging na post-strukturalisme was aanvanklik gradueel, tot en met die drastiese ommeswaai wat gekom het met die berugte studente-opstande in Mei 1968 (kyk Kritzman 1990:x-xvi).

Die aktivistiese aard van post-strukturalisme is hierna diep en sonderling in die Franse intellektuele lewe gebed. Intellektuele is hierna naamlik skerper aanspreeklik gestel vir die politieke en selfs burgerlike konsekwensies van hulle teorieë, wat meegewerk het tot waarskynlik die hoogste mate van politieke aktivisme deur intellektuele in Frankryk sedert die 1780's (vgl. Macksey 1972:11 e.v.). Hoe teensinnig Foucault (vgl. 1969b:63) ook in die middel- en laaste fase van sy loopbaan was om sy eie werk binne die voeg van strukturalisme en selfs post-strukturalisme ${ }^{8}$ te laat plaas, bestaan geen twyfel nie dat selfs die eerste middelfase teks, Madness and Civilization, asook die skerper metodologiese werke van die laat 1960's, The Order of Things (in 1965 in Frans gepubliseer) en The Archaeology of Knowledge (in 1969

8.Foucault se argeologie en genealogie sou egter teen die agtergrond van hierdie intellektuele ontwikkeling geplaas en verstaan moes word, hoe krities Foucault ook al later teenoor strukturalisme en ook post-strukturalisme sou staan (vgl. Paras 2006:167 [voetnota 28]; ook Beukes 2002b:995 ten opsigte van die onderskeie 2006:167 [voetnota 28]; ook Beukes $2002 \mathrm{~b}: 995$ ten opsigte van die onderskeie
posisies van Lyotard, Derrida en Foucault ten opsigte van sogenaamde laatposisies van Lyotarc
strukturalisme). in Frans gepubliseer), steeds skerp ooreenkomste met die strukturalisties-analitiese aksent op binêre sub-strukture toon (kyk Beukes 2002b:996 e.v.).

Argeologie het egter met meer te make as interne debatvoeringe in die 20ste eeuse sosiale wetenskappe, insluitende hermeneutiek. Dit is eerder ' $n$ konfrontasie met die Westerse ideegeskiedenis in toto (vgl. Gutting 1989:4). Tiperend van Foucault se middelfase werkswyse is dat hierdie geskiedenis nie in terme van periodes of epogge van ondersoek benader word nie (tipies andersins van moderne geskiedskrywing in die Westers-historiese ensiklopedie, bv. Pre-Sokraties, Hellenisties, Middel-Platonies, Patristies, Middeleeus en Modern), maar in terme van laagstellings van probleemstellings en problematiserings, waarmee die vergange geskiedenis juis teenswoordige inspraak verkry. In stede van ' $n$ ondersoek na die historiese ontwikkeling van byvoorbeeld die tronkwese, vra Foucault (vgl. 1990c:139) bloot: Hoe het dit gebeur dat tronkinternering die dominante vorm van straf en dissiplinering in die eietydse Westerse samelewing geword het? Of hoe het dit gebeur dat seksualiteit en seksuele oriëntasie so belangrik geword het vir die Westers-moderne verstaan van identiteit? Of hoe het dit gebeur dat waansin met publieke higiëne, met sanitasie en uiteindelik met siekte geassosieer is en wat leer dit ons van die soort rasionaliteit wat voorkeur verleen aan hierdie soort saniterende keuses, wat onproblematies van sanitasie na insanity toe kruis? Foucault volg dus 'n probleemgebaseerde benadering tot die geskiedenis, en nie 'n konvensionele periodegebaseerde benadering nie ${ }^{9}$. Argeologie is in hierdie opsig inderdaad 'n 'anti-humanistiese historiografie' (vgl. Cronin 2001:7).

In bogenoemde grootliks metodologiese en selfrefleksiewe werk, The Archaeology of Knowledge (1972), omlyn Foucault hierdie benadering as enersyds argeologies en andersyds genealogies. Argeologie neem eerstens die 'uitspraak soos dit in die argief staan' met erns (Foucault 1972:79). Met 'argief' bedoel Foucault (1972:130) 'die algemene stelsel van die formasie en transformasie van stellings' - dus alles wat argivaries wel beskikbaar is oor 'n bepaalde probleem. Die argief beslaan dus 'al die dinge wat in 'n kultuur herhaal, gespesifiseer en getransformeer' word (Foucault 1969c:66). Tweedens poog argeologie om 'diskoerse as praktyke wat in die elemente van die argief gespesifiseer word', te beskryf (Foucault 1972:131). Dit beteken dat argeologie nie in die argief op soek is na die identifisering van oorhoofse beginsels wat die ontwikkeling van 'n epog reguleer en 'n meestergeskiedenis wil postuleer nie, maar hierdie

$9 . ' n$ Probleemgebaseerde benadering tot die geskiedenis is die eerste en mees wesenlike kenmerk van 'n Foucaultiaanse argeologie. Die een uitstaande inleidingswerk tot argeologiese analise wat die afgelope twee dekades as 'n standaardteks in die navorsing gemanifesteer het, is Gary Gutting (1989) se Archaeology of scientific reason. Gutting hanteer argeologie as'n konkrete historiesanalitiese metode, wat Foucault na Gutting se resepsie ontwerp het om met baie spesifieke, ad hoc probleme in die geskiedenis van idees in die reine te kom. Gutting spesifieke, ad hoc probleme in die geskiedenis van idees in die reine te kom. Gutting onderskryf dus nie die opvatting dat Foucault se argeologiese projek se mees wesenlike oogmerk sou wees om met die sosiale wetenskappe van die 20ste eeu insluitende hermeneutiek, in debat te tree nie. In hierdie vername opsig verski Gutting se resepsie van minstens een ander gesaghebbende interpretasie, naamlik die van Dreyfus en Rabinow (1983), wat wel van die premisse uitgaan dat argeologie se mees onmiddellike impuls was om met die 20ste eeuse sosiale wetenskappe in debat te wou tree en as 'n korrektief vir fenomenologiese en strukturalistiese analises op te tree. 
totaliserende geskiedskema juis rysmier deur te fokus op watter differensies, diskontinuïteite, transformasies, mutasies, herkonfigurasies en so meer daar juis in die argief merkbaar is, daarom juis 'n ontlaging of argeologie wil postuleer (kyk Foucault 1972:9-10).

'n Meestergeskiedenis of totaliserende geskiedenis poog om die ordeningsbeginsel van 'n beskawing, epog, periode of gemeenskap, wat sowel kohesie as koherensie daaraan verleen, te vind en te beskryf. Dit aspireer om 'n homogene netwerk van verhoudinge en kousaliteite binne 'n voorafgedefinieerde stel van ruimtelike- en tydskoördinate te vestig. Dit benadruk 'n totalistiese vorm van transformasie en is gevolglik in staat om die geskiedenis in pertinente periodes en fases te verdeel. 'n Argeologie of partikuliere geskiedenis aan die ander kant, soek verdelings, afwesighede, kontingensies, mutasies en herkonfigurasies op. Dit is nie-reduktief en nie-totaliserend. Dit vra na detail en heterogene spesifisering. Dit partikulariseer die argief en beweeg anderkant die karikatuur van periodisering in die argief.

Argeologie assisteer ons om die hele netwerk van dinge wat oor ' $n$ bepaalde saak gesê is, te spesifieer in 'n stelsel van sosiale verhoudinge wat sigbaar is. Argeologie, net soos wat die geval met 'n konvensionele argeologiese opgrawing sou wees, vind dus iets 'sigbaars' in die stellinge wat oor ' $n$ bepaalde saak gemaak is en vind iets in die stellinge oor 'n saak wat 'sigbaar' gemaak kan word. Byvoorbeeld: wanneer Foucault (vgl. 1990b:137-139) oor die oorspronge en ontwikkeling van die moderne tronkstelsel navorsing doen, om daarmee op teenswoordig-historiese wyse moderne dissiplineringstelsels te analiseer (Foucault 1977b:7), rig hy die argeologiese karakter van die onderneming so in dat dit kan aandui hoe die tronk as 'n vorm van sigbaarheid ('n sigbare ding, argeologies dus 'n artefak) stellinge oor kriminaliteit produseer, terwyl stellinge oor kriminaliteit sigbare vorme produseer (die krimineel, die delinquent, die gewoontemisdadiger, die pervert, en so meer) wat die legitimiteit van die tronkwese siklies herbevestig. In 'n argeologie is daar so 'n wedersydse kondisionering tussen sigbaarhede en stellinge, tussen dinge en woorde aanwesig.

Die poging om die verhouding tussen stellinge en sigbaarhede te ontlaag, fokus eerstens op die stellinge wat die sigbare bemoontlik: in ' $n$ tronk byvoorbeeld, onder meer die instruksies aan bewaarders, die instruksies aan gevangenes, ruimtelike voorskrifte rondom die grootte van elke afdeling en sel, dieetvoorskrifte, die curriculum vir die rehabilitasie van gevangenes, interne strafmoontlikhede soos afgesonderde isolasie of voorregweerhouding, diensroosters, noodplanne, en so meer. Maar dan moet die sigbare dinge wat daaruit manifesteer, met ewe veel omsigtigheid bekyk word. Argeologiese kennis van die tronkwese beteken kennis van sowel die woorde as die dinge wat die tronklewe uitmaak. 'n Argeoloog soek immers op grond van gedokumenteerde aanwysers na artefakte. 'n Argeologie is dus ingestel op sowel wat daaroor of daarbinne gestel, geformuleer, gesê kan word, dit is die 'woorde van die tronk' as dit wat daardeur sigbaar word, die strukture, mure, uniforms, wapens, roosters, tralies, boeie; dit is die 'dinge van die tronk'. Foucault vestig hiermee die aandag op die dinamiese, wedersyds kondisionerende verhouding tussen woorde en dinge - vandaar die titel van sy eerste middelfase werk wat die aansprake van hierdie argeologie pertinent uiteensit: The Order of Things (Foucault 1970).

Argeologie fokus egter ook op die sisteem van stellinge, hoe stelbaarhede met mekaar skakel: dit fokus dus ook op een stelling se verhouding met ander stellinge, hoe die ordening van stellinge daaruit sien (Foucault 1969b:61). Hoe korrespondeer die instruksies aan bewaarders met die instruksies aan gevangenes? Hoe korrespondeer die pligskedule van gevangenes met die dieetvoorskrifte vir gevangenes? Die ordening van stellinge voorsien 'n argeologie van die wyse waarop 'n sisteem van dinge sigself orden. Verder fokus argeologie op die herhaalbaarheid van stellinge en poog om die reëls vir herhaalbaarheid van stellings te identifiseer. Stellings wat herhaal word, dui op prosedures. Prosedures weer, dui op die wyse waarop dinge georden word. Wanneer 'n stelsel van prosedures geïdentifiseer is, word toegang verkry tot 'n begrip van die ordening van dinge self. Daarby poog 'n argeologie om die posisies wat vir subjekte deur stellinge geskep word, te identifiseer. Watter soort praktyke word vir 'n subjek deur die stellinge bemoontlik? In terme van die tronkvoorbeeld, wat beteken dit volgens die aangebode stellinge om 'n rehabiliteerbare gevangene, 'n gewoontemisdadiger, 'n jeugoortreder, 'n maksimum sekerheidsgevangene, 'n bewaarder, 'n maatskaplike werker te wees? Watter subjektiewe rolle wat deur mense opgeneem kan word, word dus deur die stellinge bemoontlik?

Argeologie fokus bykomend op die institusionele ruimte as die gesanksioneerde, outoritêre domein waar die ordening van dinge sowel gepresenteer as die handelinge van subjekte begrens word (Foucault 1969b:61). Die institusie bemoontlik sekere aktiwiteite en verbied ander aktiwiteite. Hoe die institusie dit doen, het te make met byvoorbeeld ruimtelike oriëntasie en ruimtelike inperking in 'n tronk: die argitektoniese uitleg daarvan, die sel en selinhoud, die posisionering van ' $n$ toilet waar meer as een gevangene in 'n sel is, die plasing van 'n studietafel, of nie, die uitleg van gemeenskaplike ontspanningsgrond vir gevangenes, die inrig van meer of minder rye vir opdiening in die eetsaal, die moontlikheid al dan nie van fisiese kontak met geliefdes in besoekruimtes, en so meer. Al hierdie 'dinge' in die tronk presenteer sowel die ordening van dinge in die tronk as die wyse waarop die handelinge van subjekte begrens word.

Laastens is argeologie ook geïnteresseerd in die jargon of woordeskat wat deur die wedersyds kondisionerende verhouding tussen woorde en dinge gegenereer word, of anders gesê, die sistematiese wyse waarop diskursiewe objekte toeganklik gestel word (Foucault 1969b:61). So is daar in kriminologie, patologie, strafreg en die sogenaamde 
Polizeiwissenschaften ' $\mathrm{n}$ hele woordeskat gegenereer om die verskynsel van onder meer kriminaliteit, vonnis, internering, dissiplinering, straf en rehabilitasie toeganklik te stel vir subjekte wat self nie geïnterneer is of binne die industrie van dissiplinering werksaam is nie. So word dit moontlik om van die tronk 'diskoers' te maak, iets wat produktief en publiek gestel is, waaroor voortgaande gepubliseer en gepraat kan word - juis deur diegene wat nie veronderstel was of is om iets daarvan te verstaan nie (vgl. Foucault 1975b:180, 1990b:101). So word almal kundiges van 'n dissipline waaraan hulleself onderworpe is, maar nie 'herken' nie: Foucault se hele bedoeling is om die moderne samelewing juis as 'n omvangryke panoptiese argief uit te beeld. Argeologie is die eerste tree in daardie analise.

Samevattend sou beweer kon word dat Foucaultiaanse argeologie as ' $n$ middelfase probleemgebaseerde benadering tot die geskiedenis:

- die wedersyds kondisionerende verhouding tussen die stelbare en die sigbare, tussen woorde en dinge, karteer

- die verhouding tussen stellinge analiseer

- reëls vir die herhaalbaarheid van stellinge met die oog op die identifisering van prosedures formuleer

- die posisies wat met betrekking tot die stellinge tussen subjekte gevestig word, analiseer

- institusies, wat die ordening van dinge presenteer sowel as die aktiwiteite van subjekte begrens, beskryf

- die woordeskat wat deur die verhouding tussen woorde en dinge gegenereer word, analiseer.

So 'n argeologie is nie bloot provokatief nie, maar duidelik 'n produktiewe analitiese gereedskap ${ }^{10}$ (vgl. Kendall \& Wickham 1999:26): enige sosiale stelsel bestaande uit woorde en dinge (en geen sosiale stelsel bestaan geredelik sonder beide nie) sou hiervolgens geanaliseer of ontlaag kan word, vanaf byvoorbeeld teologieë of kerke (vgl. Beukes 2008), prospektusse of organisasies (vgl. Clegg 1998) tot by dobbelstatute of casinos (vgl. Hunter 2010). Die argeologie moet ter wille van volle diskursiewe ontplooiing egter aangevul word deur 'n tweede middel-Foucaultiaanse konsep, naamlik genealogie.

\section{Genealogie}

Genealogie moet as 'n verbreding en uiteindelik 'n verplasing van die aansprake van argeologie verstaan word ${ }^{11}$. Dit neem dieselfde middelfase elemente ten opsigte van teenswoordige geskiedenis en argeologie oor, met aksent op die analise

10.Paras (2006:1-18), in 'n uitstaande inleidingshoofstuk gettel 'Into the archive', duil aan hoe Foucault se werk gedurende die laaste fase van sy loopbaan vanaf 1978 to 1984, veral sy lesings by die Collège de France in die laat-1970's en vroeg-1980's, die diskoersanalitiese effek van hierdie produktiewe gereedskap wou behou, maa met groterwordende klem op die magsanalitiese elemente van genealogie en hoe dit sou kon meewerk tot ' $n$ onmoderne verstaan van die emansipasie van die subjek.

11.Vir ' $n$ bespreking van die verbreding van argeologie na genealogie, as sou dit 'n meer pertinente kontra-moderne poging wees om fenomenologiese en strukturalistiese tendense in die moderne sosiale wetenskappe te ondergrawe kyk Dreyfus en Rabinow (1983:xvii-xxvii). Vir 'n kritiese bespreking van Dreyfus en Rabinow se Foucault-resepsie, kyk Paras (2006:52-57). Vir ' $n$ analise van die Nietzscheaanse agtergronde van genealogie (ruimte ontbreek om dit hier aan die Nietzscheaanse agtergronde van genealogie (ruimte ontbreek om
orde te laat kom), sien Mahon (1992) en Beukes (1996:233-236). van die verhouding van woorde en dinge in die argief, maar voeg drie kritiese elemente daarby: institusionele ontwikkeling, selfrefleksiwiteit en magsanalise (Foucault 1980:79). Moontlik sou die verhouding tussen argeologie en genealogie verduidelik kon word as die verskil tussen metode en taktiek: argeologie is metodies, en genealogie takties in die wyse waarop dit argeologie implementeer. Genealogie sou dus beskryf kon word as die strategiese, praktykgerigte ontwikkeling van argeologiese navorsing (vgl. Foucault 1980:85 ${ }^{12}$ ). Die verhouding tussen argeologie en genealogie is belangrik genoeg dat dit die middelfase in die oeuvre self weer in twee duidelike seksies periodiseer en daarom sal ons hier in 'n samevatting ook aandag gee aan die verhouding tussen argeologie en genealogie.

Die genealoog is nie soos die argeoloog 'n opgrawer in die argief nie, maar'n diagnostikus wat op die verhouding tussen mag en kennis fokus. Anders as by argeologie, word praktyk in genealogie belangriker as teorie (Dreyfus \& Rabinow 1983:16). Maar dit is 'n praktyk van 'die gekompromiteerde binnekant' af, eerder as vanuit die perspektief van die afstandelike waarnemer - daardie klassieke moderne subjek, handelend en wetend, wat tog, hoe gesubversiveerd ook al, in Foucault se vroegste werke nog wel teenwoordig is.

In die ontwikkeling van die genealogiese projek kom Nietzsche se magsfokus die eerste keer pertinent by Foucault na die voorgrond. Foucault neem by Nietzsche die opvatting oor dat alle objektiewe aansprake subjektiewe belange maskeer en dat ongeluk en kontingensie die skynbaar onkeerbare teleologiese mars van die geskiedenis bepaal. Oombliklik word genealogie 'n opponent van die tradisionele geskiedsbegrip, juis in die fokus op die subversiewe aanspraak van wette en finaliteite in die moderne geskiedsbegrip. Soos met argeologie, is dit gekant teen kontinuïteit en ten gunste van diskontinuïteit, maar dit fokus nie langer op diepte in die argief nie. Geneaologie is juis gerig op die skynbaar oppervlakkige en onverwagse, die 'persoonlike dinge', die subjektiewe elemente in die argief.

Soos wat dienaam aandui, fokus genealogieop dieontwikkeling van die verhouding tussen woorde en dinge in die argief. Genealogie wil die oorspronge van hierdie diskoerse in die argief identifiseer, aanvanklik hoé diskoerse dus in terme van die verhouding tussen woorde en dinge gevorm word, maar veral, waarom diskoerse institusie-histories varieer. Dit vra eenvoudig: hoe het hierdie bedryf, stelsel, institusie, tot hier gekom? ${ }^{13}$ Hoe byvoorbeeld, het psigiatrie in terme van die ontwikkeling van die hantering van waansinniges vanaf die Middeleeue - waar waansin soos reeds opgemerk as

12.Die literatuur oor Foucaultiaanse genealogie en die praktiese implementering daarvan in ' $n$ verskeidenheid van sosiale subsisteme is stelselmatig besig om tot die onoorsigtelike te ontwikkel. Die belangrikste werk oor die betrokke tema is myns insiens in die Engelstalige wêreld gedoen of in Engels beskikbaar gemaak deur Ewald (1992:169-175), Fraser (1981:272-287), Mahon (1992), May (1993), Prado (1995), Turner (1995:372-387) en Visker (1995).

13.Inderdaad, soos Dreyfus en Rabinow (1983:109) dit stel, is die wêreld vir middelFoucault nie " $n$ drama waar ' $n$ werkliker werklikheid 'n masker dra en net af en toe van agter die gordyn te voorskyn kom nie', maar dit 'is soos wat dit is ... Die wêreld is soos wat dit tot die oppervlakte kom, immanent en materieel: dit is die genealoog se insig'. 
alternatiewe kennisvorm gefunksioneer het en die uitsprake van waansinniges as ' $n$ unieke wysheidsvorm en geleier tot selfinsig begryp is - tot by die ostrasering van waansinniges in 'huise van waansin' of op die 'skip van gekke', tot by die internering van waansinniges in gespesialiseerde hospitale in die moderne periode, tot by die oënskynlik gerespekteerde dissipline in die mediese wetenskap, gevorder? Wat in die argief tussen woorde en dinge ten aansien van waansin het psigiatrie as uiteindelike wetenskap bemoontlik? Hoe het delirium 'n vorm van kennis geword (kyk Foucault 1965:85 e.v., 159 e.v., 1973:107-123)?

Dieselfde geld vir Foucault se aweregse genealogieë van ander moderne institusies: dissiplinering en straf in die tronkwese, in terme van die ontwikkeling van die absoluut soewereine monargiese straf van die vroeg-moderne periode tot by selfregulerende dissiplineringstraf in moderne tronke, vanaf Bentham se panoptiese struktuur tot by die komplekse, selfperpetuerende industrie van dissiplinering in die moderne penitentiary; en die parallele studies met betrekking tot die ontwikkeling van moderne fabrieke, skole, polisiëringsinstansies, hospitale en klinieke. In al hierdie genealogieë speel die vraag na die produktiewe effek van mag 'n belangrike rol - 'n saak waarop ons aanstons terugkom.

Soos reeds betoog, die opvatting van teenswoordige geskiedenis ondervang elkeen van die middel-Foucault se analitiese konsepte. Dit is duidelik in sy genealogiese projek: In al Foucault se middelfase werke is 'n fokus op historiese ondersoek en interpretasie aanwesig wat nie spruit uit ' $n$ belangstelling in die verlede nie, maar vanuit ' $n$ diepe verbintenis om die teenswoordige te begryp. Genealogie is die projek wat die spoor van die hede in die verlede opsoek en identifiseer, sonder dat dit as eerste oogmerk 'n respektable rekonstruksie van die verlede wil wees. Dit word gedoen vanuit die opvatting van die versteurde subjek en al die ander oorwegings wat in die tweede afdeling van hierdie artikel ten opsigte van teenswoordige geskiedenis gedien het. Genealogie onderskei so teenswoordig-histories twee modi van magsuitoefening of dominansie in die Westerse geskiedenis: die 'tradisionele' en die 'dissiplinerende', ${ }^{14}$ wat twee vorme van magsuitoefening is wat skerp gekontrasteer moet word. Foucault se myns insiens sentrale teks in die middelperiode van sy loopbaan, Discipline and Punish: The birth of the prison, begin (Foucault 1977b) met 'n beskrywing van die bloedige teregstelling van die koningsmoordenaar Robert-Francois Damiens op 02 Maart 1757:

Die weefsel is van sy arms, heupe en kuite met 'n rooiwarm knyptang weggeskeur, in sy regterhand hou hy die mes waarmee hy die moorde gepleeg het, met swael op elke brandplek uitgestrooi, gesmelte lood en kokende olie oor sy hele liggaam uitgegooi ... uiteindelik is sy liggaam uitmekaargeskeur deur vier perde wat vanaf die arms en bene in verskillende rigtings hardloop, met 'n laaste vuur wat dit alles tot as verbrand ... (p. 3)

Ongeveer 80 jaar later is die regulasies vir die Huis vir Jeugmisdadigers in Parys opgestel. Die regulasies sluit in:

14.Die teenswoordige deelwoord binne die konteks van genealogie as ' $n$ vorm van teenswoordig-historiese analise is belangrik.
Om halfagt die aand in die somer en halfnege in die winter, moet die gevangenes terug wees in hulle selle, nadat hulle hande gewas het en hulle klere in die binnehof skoongemaak is; na die eerste dromrol moet hulle uittrek en na die tweede dromrol moet hulle in die bed klim. (Foucault 1977b:7)

Wat het in daardie 80 jaar gebeur ten opsigte van die uitoefening van mag? Die eerste scenario is vanselfsprekend 'n teregstelling en die tweede 'n skedule - maar die mentaliteitsverskil ten opsigte van magsuitoefening is duidelik. Hier illustreer Foucault (1997b:3-10) die verskil tussen tradisionele, brutale, voorhande magsuitoefening in die vroeg-moderne periode, en die veel meer geslepe, berekende vorm van tipies-moderne magsuitoefening in die dissiplineringshandeling, in 'n skedule. Dissiplinering het tradisionele magsuitoefening in minder as 'n eeu vervang 'n eeu waarin publieke smaak vir die spektakel van fisiese straf verander het en mettergaande as 'wreed' bestempel is - terwyl dit voorheen onproblematies aanvaar is as die wyse waarop mag funksioneer: sigbaar en teenspraakvry, soos met die teregstelling van Damiens. Straf begin in hierdie periode stelselmatig wegbeweeg vanaf die liggaam na die 'siel' en die 'wil'. Ekstreme strafgeweld ten aansien van die liggaam het drasties afgeneem en het plek-plek in Europa heeltemal verdwyn, maar is konsekwent vervang met komplekse, subtiele vorme van korrigering en sensuur. Foucault (1977b:101) is daarvan oortuig dat die moderne samelewing van toe af nie onderhou word deur 'n sigbare staatsapparaat of deur minimum konsensus waardesisteme nie, maar deur verskuilde tegnieke van dissiplinering wat in elke sosiale institusie aan die werk is.

Hierdie sosiale institusies is daarom ook die eietydse teiken van Foucaultiaanse genealogie. Die ontwikkeling van hierdie institusies word met presisie deur Foucault (1997b:100 e.v.) gedokumenteer: Die tegnieke van dissipline en waarneming wat byvoorbeeld gevestig is in die nuwe tronkstelsel van die laat 18de eeu, wat sigbaar word vanaf Pennsylvania in die VSA tot in Noord-Oos Duitsland, is ontleen aan drie eeue se dissiplineringspraktyke in ander sosiale sfere, veral in staatskole en die weermag. Vandaar die verstommende ooreenkoms tussen die nuwe tronke en die ander institusies van die 'dissiplineringsera', soos Foucault (bv. 1977b:104) die laaste dekade van die 18 de eeu graag as sinoniem vir 'modern' benoem: onder meer hospitale, klinieke, fabrieke, sub-ekonomiese behuisingskomplekse, kantoorgeboue, skole en weermagbarakke. Die Britse filosoof Jeremy Bentham se ontwerp vir die 'perfekte moderne tronk', die Panoptikon, 'n sirkelgebou met 'n sentrale wagtoring vanwaar gevangenes (of fabriekswerkers, of skoliere, of pasiënte, of troepe, of kantoorwerkers, of woonstelbewoners) waargeneem kan word sonder dat hulle die waarnemer kan waarneem, is die wendingsontwerp wat moderne institusionele beheer bemoontlik. Ironies is geen Panoptikon volgens die presiese voorskrifte van Bentham ooit gebou nie, maar die sentrale idee grondliggend aan die ontwerp - om waargeneem te word sonder om die waarnemer waar te neem en daarom so op te tree asof die waarneming absoluut konstant en permanent aanwesig is - is volgens Foucault (1977b:195-230) 
deur elke moderne institusie verinwendig en is tot vandag toe in elke aspek van tegno-fascisme aanwesig, vanaf gesloteveld kameras tot by die verspotte, selfpubliserende Facebook - sekerlik na Foucault die laat-moderne laagtepunt van die Westerse kultuur.

Die Panoptikon as 'n beslissend optiese prosedure is vir Foucault die sentrale metafoor van moderne dissiplinerende magsuitoefening. Juis omdat hulle van die alomteenwoordigheid hoewel onsigbaarheid van die panoptiese samelewingstruktuur bewus is, kan subjekte hulleself begin polisieer (inderdaad Bentham se oorspronklike intensie), wat die Foucaultiaanse diagnose wat die outeur elders (Beukes 2009a:5) die 'OCNE-beginsel' noem, tot gevolg het: Moderne subjekte het die ervaring dat hulle konstant waargeneem word ('observation'), moderne subjekte het die ervaring dat hierdie waarneming 'n kontrole-intensie het ('control'), moderne subjekte word hierdeur 'genormaliseer' in die sin dat moderne subjekte konformeer aan die waarneming of kontrole ('normalisation'), en moderne subjekte begin hulleself dan op sterkte van die 'norm' eksamineer ('examination'). Dit is juis omdat moderne subjekte bewus is van panoptiese (oral, maar daarom juis onsigbare) magsuitoefening, dat moderne subjekte hulleself in die moderne epog polisieer en dissiplineer. Brute mag is dan oorbodig en by verre minder effektief as OCNE. Moderne institusies se sentrale kenmerk is volgens Foucault (1977b:170-194) dus die aanvanklik argitekturele en geometriese nabootsing van die Panoptikon, maar mettergaande en uiteindelik die volledige internalisering van die dinamika van waarneming, kontrole, normalisering en eksaminering.

Die 18de eeu is ook uniek omdat die menslike liggaam die eerste keer geteiken word as 'n domein van manipulasie en korreksie (Foucault 1977b:293 e.v.). Die liggaam word in die 18de eeu gekonseptualiseer as 'n 'masjien', wat meganies verstel, georganiseer en verfyn kan word - 'n liggaamsbeskouing wat volledig afwesig is in die 17de, vroeg 18de, of enige voorafgaande eeu. Die 'ontdekking' van die liggaam as 'masjien' bemoontlik die ontwikkeling van 'n 'politieke anatomie' (Foucault 1977b:28) waar mag 'tot die wese van die individu deurdring, tot in die diepste liggaamlikheid van individualiteit, en sodoende liggaamshouding, postuur en spraak bepaal - wat mense sê, hoe hulle leer om waarneembaar te leef en te werk tussen ander mense' (Foucault 1977b:29). Elke aspek van optrede, selfs die mees geringe en triviale, word onderwerp aan analise en ondersoek: daarom is regulasies in institusies vanuit hierdie periode so gedetailleerd, inspeksies so noodsaaklik, en toesig altyd baie naby. Groot aandag word in hierdie tyd aan juis die postuur van skoolkinders en die marsjeerroetines van soldate gegee - nogeens sonder enige historiese presedent. Watter institusie of organisasie ook al aan die orde was, dissipline sou wentel om die kleinste detail van die lewens van die subjekte wat daarbinne staan of daaraan onderwerp is - en niemand word vinniger onderwerp as juis 'n skoolkind of 'n infanteris nie (vgl.
Foucault 1990b:105). Moderne dissiplinering, OCNE, sou daarom analogies gou 'n sellulêre stelsel van die lokalisering en konsentrasie van individue in 'n beheerbare ruimte afdwing: In die tronksel, in die werkstasie in die fabriek, in burokratiese en administratiewe kantore, in die menasie by die garnisoen, in die hospitaalsaal, in die klaskamer. Hierdie ruimtes word beheer deur skedules, diensroosters, buite-perke areas, klokkaarte en handleidings, wat almal die bedoeling het om 'n 'ekonomie van die liggaam' op grond van die tersaaklike bevel en ruimte-afskorting of -uitsluiting af te dwing. Individue word 'subjekte' in die pejoratiewe sin, studiegevalle, wat konstant binne hierdie geperkte ruimtes aan die tersaaklike regulasies getoets, beskryf, vergelyk en getakseer word. Die geleefde lewe van die individu word so in studienotas, prestasienotas en produksienotas vertaal. So verloor die andersins wispelteurige menslike liggaam alle misterie. Dit word meganies en 'n verlengstuk van die dissiplineringsmeganismes van die maatskappy.

Gelyktydig tot die ontwikkeling van die meganiese liggaamskonsep, is daar in die laat 18de eeu die ontwikkeling van wat Foucault (1978:140 e.v., 1977b:104 e.v.) 'bio-mag' noem. Hierdie ontwikkeling het te make met die diverse tegnieke wat in die laat 18 de eeu ontwerp word vir die beheer van bevolkings en bevolkingsgroepe - wat self natuurlik beheer oor die liggaam vooronderstel. 'n Enorme belangstelling word via bio-mag in seks opgewek: fornikasie, sowel as enige aanloop en enige afloop daarvan, word die wentelpunt van sowel liggaamlike as bevolkingsbeheer. In die vroeg 19de eeu word seksualiteit volgens Foucault ontwerp om bio-mag te akkommodeer: byvoorbeeld, woorde word geskep, meesal vanuit die reeds afstandelike Latyn, om 'n outoriteitsruimte te vestig en dit vir subjekte moontlik te maak om onbetrokke oor seks(ualiteit) te kan praat, sonder dat dit onmiddellik die gedagte aan fornikasie hoef op te roep: so vervang 'penis', 'vagina', 'koitus', 'anaal', 'oraal' en 'masturbasie', om enkeles te noem, die woorde wat in enige samelewing bestaan (het) om oor die verwysdes van hierdie woorde te praat. So word dit onnodig en selfs onmoontlik om van p..s in die fatsoenlike, modern-OCNE ruimte van panoptiese beheer te praat, wanneer die korrekte woord na bio-magswerking eintlik 'vagina' is. Trouens, die 'outentieke' woorde soos 'p..s', ${ }^{15}$ waarvoor daar eenvoudig 'n variant in elke taal moet wees, en wat die enigste en juis 'normale' woord voor die 19de eeu was, verkry nou die status van vulgariteit, smerigheid en laster. ' $n$ Mens kon in die 19de eeu skielik tronkstraf kry deur iemand ' $n$ 'p..s' te noem - en in die 21ste eeu is dit teoreties steeds moontlik, mits die relevante strafregtelike intentio ten opsigte van laster natuurlik aanwesig is:

Die probleem is dat seksualiteit, in die mate waarin dit wel in die liggaam as sodanig vestig, 'n problematiese plek het: die geslagsorgaan is nie soos ' $n$ hand, hare, of neus nie: Dit moet beskerm en omring word, dit vra om ' $n$ investering van regspraak - so 'n investering is volledig afwesig voor die 19de eeu, dit is uniek aan die moderne. (Foucault 1990d:201-202)

15.Die outeur is selfeksaminerend te modern-genormaliseerd om die betrokke woord uit te skryf. 
Bio-mag ontwerp so 'n taalbeheer ter wille van bevolkingsbeheer. Met hierdie taalbeheer word dit moontlik om te begin kategoriseer: Foucault (1978:105) dui aan dat vier wesenlike kategorieë in die vroeg 19de eeu geskep word ter wille van onmiddellike en effektiewe bio-beheer en waarteen dissiplinerend opgetree moes word: die histeriese vrou of nimfomaan, die masturberende kind, die Malthusiaanse egpaar (wat meer kinders het as wat hulle ekonomies kan bekostig as gevolg van 'n gebrek aan 'beheer'), en die volwasse seksuele pervert. 'n Hele aantal pogings om die seksuele gedrag van die bevolking te 'normaliseer' word hiervolgens in plek gestel. Die norm wat hierdie 'normalisering' dra, word geskep en in stand gehou deur 'n nuwe klas professionele persone, of 'n ou klas, soos die priesters, wie se rol geherdefinieer word ten opsigte van die instandhouding van die 'normale' en selfs 'sedeliknormale': dit sluit in gesondheidswerkers, maatskaplike werkers, regters, dokters, predikante, onderwysers, en so meer. Hierdie persone is voortaan verantwoordelik vir die instandhouding van die norm van bio-mag deur die 'liggaam en siel van die samelewing konstant waar te neem' (Foucault 1977b:184). En hulle is oral:

Die regters van normalisering is alomteenwoordig. Ons leef in 'n samelewing van die onderwyser-regter, die dokter-regter, die dosent-regter, die maatskaplike werker-regter, ja, die regterregter. Dit is in hulle waar die universele heerskappy van die normatiewe gevestig is, en elke individu, wie en waar ook al, moet aan hulle konstante blik die liggaam, die houding, die gedrag, die voorliefdes, die prestasies, onderwerp. (p. 304)

Moderne institusies se beheersoekende ontwikkeling moet volgens Foucault dus in die ontwikkeling van politieke anatomie en bio-mag teruggevind word. Die despotiese karakter van hierdie dissiplineringsmodus van magsuitoefening is gevestig in die wese van die moderne samelewing en elke institusie daarbinne. Foucault rig sy genealogie daarom op die ontmaskering van hierdie konfigurasie van mag. Dit doen genealogie, as gebed in teenswoordige geskiedenis, deur tweede-orde oordele as't ware weg te spel; weg te doen met pasklaar sinteses oor wat reg en wat verkeerd, wat donker en wat Verlig is: dit fokus brutaal op kontingente ontwikkeling en die oopskryf van stiltes van die Ander in die argief.

Uiteindelik moet genealogie egter introspektiewe afmetings aanneem: genealogie wil ons begelei om die institusionele kontingensies wat ons gemaak het wat ons is, of ons per abuis 'veroorsaak' het, te herken; maar meer, om verby daardie kontingensies te beweeg, sodat ons bevry kan word om te dink soos wat ons tot dusver nie kon dink nie, en te wees wat ons tot dusver nie kon wees nie (Foucault 1990b:101). Genealogie is selfrefleksief omdat dit 'n instrument van bevryding wil wees; nie in terme van die gewaande emansipatoriese potensiaal wat in Verligtingsaansprake opgesluit lê nie, maar in terme van 'n uitbreiding van die limiete van noodsaaklikheid en noodwendigheid. Daarvanuit fokus Foucault se latere werke 'esteties-eties-emansipatories' op 'n 'kritiese ontologie van die Self' (Foucault 1984:47; kyk Visker 1995: 62-65; vgl. Kendall \& Wickham 1999:32-34).
Ons sou die kritiese aansprake van genealogie as 'n middelfase analitiese konsep by Foucault so kon opsom. Genealogie:

- beskryf stellinge in die argief, maar met nadruk op die relevante institusie en die betrokke institusie se magselemente, veral die taal van die institusie, wat daarin opgesluit is

- oriënteer sigself aan teenswoordige geskiedenis in die eerste-orde naspeur van institusionele ontwikkeling

- wys magsverwante verskuiwings in institusionele ontwikkeling uit wat voortdurend herkonfigureer en andersins versweë sou bly

- beskryf stellinge in die argief teenswoordig-histories as 'n voortgaande proses

- is selfrefleksief en bevorder die beweging na 'n kritiese ontologie van die Self.

Hoe vergelyk argeologie en geneaologie met mekaar? Die volgende twee stellings sou die verhouding en verskil tussen die twee konsepte kon beskryf, met inagname van dit wat tot dusver oor die teenswoordig-historiese verskuiwings rondom waansin, seksualiteit en dissiplinering in die moderne periode verduidelik is:

- Argeologie ontbloot die regulasies wat sosiale praktyke reguleer en beheer, en wat vir die betrokke agente van kennis of handeling onkenbaar of onbekend is. Genealogie weer, dokumenteer die uniekheid van oppervlakte gebeurtenisse, is sensitief vir die betekenis van klein detail, klein verskuiwings en subtiele kontoere wat die individu ten diepste raak. Institusionele ontwikkeling en selfrefleksiwiteit is daarom twee kritiese elemente wat genealogie by argeologie voeg.

- Argeologie funksioneer as 'n opgrawing, waar diepte en die reikwydte van die argief oor 'n bepaalde saak ondersoek word en artefakte in terme van woorde en dinge vanuit die argief aangebied word. Genealogie weer, funksioneer as't ware as 'n ongeluksverslag, in die sin dat ongeluk, toeval, kans, spontaniteit, leuens, selfbelang, en so meer gedokumenteer word in terme van die effek wat dit op die argief uitoefen.

\section{Diskoers}

Hoe skakel die laaste middel-Foucaultiaanse konsepte wat ons hier hanteer, 'diskoers', en daarby inbegrepe 'magsanalise', met argeologie en genealogie? Die wesenskenmerk van diskoers is nou reeds duidelik: diskoers, die voortgaande wisselspel tussen en wedersydse kondisionering van woorde en dinge in die argief, produseer. Dit is die sentrale kategorie van Foucault se opvatting van 'diskursiewe formasie' (Brown \& Cousins 1994:196). Mediese diskoerse oor 'waansin' en 'onredelikheid' produseer die geestesongesonde pasiënt, strafregtelike diskoerse produseer die krimineel, diskoerse oor seks produseer seksualiteit, fetisjes, taboes, en so meer. Wanneer woorde en dinge in die argief mekaar wedersyds kondisioneer, het dit materiële implikasies - iets gebeur, iets kom na die oppervlakte. Diskoers gaan dus nie bloot oor taal en taalfunksies nie, maar wat gebeur wanneer taal en die 'orde van dinge' mekaar kondisioneer. 
Seksuele taboes op grond van bloedverwantskap, die viering van seks in antieke kulture as ars erotica, die afwysing van die vleeslike in die Christelike tradisie, tel byvoorbeeld onder die voorlopers van dit wat vanaf die $18 \mathrm{de}$ eeu diskursief 'seksualiteit' sou word. Seks het nie in 'n suiwer pre-diskursiewe vakuum bestaan en as't ware gewag om diskursief as 'seksualiteit' ontdek te word nie. Maar sedert die 18 de eeu het die woorde en dinge in die argief van seks mekaar begin kondisioneer in terme van die verhouding tussen kennis en mag. Die manier hoe oor seks gedink en gepraat is, het verander; die wyse waarop seks publieke voorkeur in studies, dokumentering en ideaaltipes in terme van publieke gesondheid begin kry het, staan in skrille kontras met die privatistiese, pre-diskursiewe kwaliteite daaromtrent in die ars erotiese voorgeskiedenis tot die moderne. Seks wat 'seksualiteit' word, dui, soos voorheen aangedui, 'diskoers' aan.

Foucault se opvatting van 'diskoers' bied dus geskiedenisse van idees aan, wat juis nie die geskiedenisse van die bedinkte idees tot op die gegewe stadium van ondersoek, was nie. Skerper sou ' $\mathrm{n}$ mens kon stel dat diskoers, in terme van ' $\mathrm{n}$ teenswoordig-historiese oriëntasie, nie bloot 'n geskiedenis van idees of menings oor ' $n$ saak is nie, maar' $n$ rekonstruksie van die voortgaande, materiële, manifesterende aspek van idees (vgl. Deleuze 1994:268). Hierin is 'n wesenlike epistemologiese oortuiging, wat voorwaarde vir die verstaan van diskoers is, opgesluit: Foucault argumenteer taalfilosofies (Davidson 1997:1) dat ons oor geen kognitiewe proses beskik voordat ons woorde gebruik nie - daar bestaan nie iets soos ' $n$ vooraf kognitiewe handeling wat dan in woorde uitgedruk word nie. Wanneer ons ietwat Wittgensteiniaans 'n eenvoudige wiskundige diskoers gebruik, kan die punt goed geillustreer word: $\mathrm{y}=2 \mathrm{x}+5$; indien $x=2$; dan $y=9$, $23,51(2 \times 2+5=9 ; 2 \times 9+5=23 ; 2 \times 23+5=51$, ens. $)$. Op watter stadium in hierdie berekening word dit moontlik om die volgende syfer te 'dink'? Dit kan net gebeur indien die berekening (of diskursiewe handeling) uitgevoer word wat tot daardie syfer lei. Daar is geen vorm van denke wat onafhanklik van die berekening tot die syfer kan lei nie. Die uitvoer van die berekening produseer die materiële voorwaardes vir die 'volgende syfer'. Die 'volgende syfer' kan nie in terme van ' $n$ algemene fakulteit bedink word nie, maar slegs volgens 'n bepaalde tegniek, in hierdie geval, die tegniek van algebra. ${ }^{16}$ Dit beteken dat kennis 'sonder ons voortgaan' - dat die voorwaardes vir kennis onafhanklik van die subjek opereer.

Wanneer Foucault (1978:15-37) dan byvoorbeeld die Katolieke biegpraktyk as die stimulus vir die moderne diskoers van seksualiteit ondersoek, benadruk hy dat die 'sondes van die vlees' nie iets is wat vooraf in die denke gesitueer is nie, maar iets wat histories verskyn op die oppervlakte van 'n organisasie van stellinge en tegnieke rakende seks binne die argief. Hy dui vanuit die argief onder meer aan dat die bieg, vanaf die latere patristiek, deur die vroeë Middeleeue, tot net voor die Italiaanse Renaissance, 'n 16.Die wiskundige voorbeeld is ontleen aan Kendall en Wickham (1999:35); vergelyk ook Paras (2006:21). onbelangrike kerklike ritueel was wat hoogstens een maal per jaar afgedwing is. Foucault (1977b:60 e.v.) dokumenteer dat daar gedurende die Renaissance toenemend druk uitgeoefen word om weekliks bieg te doen en dat die reëls vir die bieg vir beide biegdoener en priester op allerlei wyses in hierdie tyd verander: hierdie veranderinge het net een doel, en dit is om fornicatio ('seksuele sonde', pertinent vaginale penetrasie) te prioritiseer. Gedurende die Renaissance word fornicatio, vroeër minstens gelykgestel aan gula (vraatsug) en socordia (luiheid), se posisie op die Katolieke sondeleer gewysig as die 'oersonde'. Vir die eerste keer word nie alleen fornikasie, selfs tussen getroude mense, bloot handelingsgewys as oersonde geoormerk nie, maar word ook bloot die idee van of aan fornikasie geprioritiseer as iets wat publiek gemaak moet word, na die oppervlakte gebring moet word. Dit is ' $n$ goeie voorbeeld van hoe diskoers opereer: wat is die berekeninge wat gemaak is om by die syfer 'seks' te arriveer? Hoe het dit publiekstellende momentum verkry? Vir Foucault is hierdie berekening die voorwaarde vir die moontlikheid van diskursiewe kennis (vgl. Turner 1995:386).

Uit hierdie voorbeeld word 'n aantal kenmerke van diskoers as ' $n$ middelfase element in Foucault se analises duidelik. Diskoers:

- is produktief, in die sin dat dit die wedersydse kondisionering tussen woorde en dinge in die argief na die oppervlak bring

- dui die veranderinge aan waarmee 'n bepaalde saak histories beskryf is en hoe dit skakel met die wyse waarop dieselfde saak teenswoordig beskryf word

- produseer die berekenings of die materiële voorwaardes vir die verstaan waarop idees aangaande 'n bepaalde saak publiekgestel word of institusionele kwaliteit verkry.

Uiteindelik wil die aangeduide sambreelbegrip 'teenswoordige geskiedenis' en daaruitvoortvloeiend die konsepte argeologie, genealogie en diskoers meewerk tot die ontplooiing daarvan in wat na Foucault genoem kan word, 'magsanalise'. Mag word nie deur Foucault pejoratief hanteer as sou dit by voorbaat op 'n negatief dui nie. Mag is oral en word nie uitgeoefen deur die wat 'bo' is op die wat 'onder' is nie (vgl. Foucault 1977d:220). Mag word nie deur een agent besit nie: mag word uitgeoefen. Mag is nie agteraf of subversief aan die werk nie. Mag is voor en agter, bo en onder. Mag produseer in hierdie sin kennis. By Foucault is dit nie 'Kennis is Mag' nie, maar 'Mag is Kennis'. Wat ook al bepaal waaroor gepraat kan word, bepaal ook wat geken kan word. Mag spoel anoniem deur elke idee en handelingskonteks en orden uiteindelik alles in die argief; onderhou die verhouding tussen die stelbare en die sigbare binne die argief.

Geen masjien het ooit klaar gewerk nie. Dit werk nou en sal later weer moet werk. Wat dit laat werk, is meganiese mag of krag. Net soos wat mag of 'krag' na die tegniese proses verwys waarmee byvoorbeeld brandstof 'n enjin opwek, terwyl die opwekking altyd onvoltooid of onafgehandeld is, wek mag beweging of dinamika in die samelewing op, sonder dat dit ooit 'klaar' is. Dit hou dus sosiale beweging aan die beweeg. 
Maar op hierdie beweging sou daar altyd teenkragte moes wees: die ontbrandingsproses self, slytasie en weerstand. Geen masjien werk sonder ' $n$ vorm van brandstof maar ook sonder ' $n$ vorm van weerstand nie. Presies so geld dit vir die funksionering van mag in die samelewing: Mag is nooit klaar opgewek nie en word ten aansien van weerstand uitgeoefen. Vir Foucault is die weerstand teen mag net so integraal deel van mag as die magshandeling of 'beweging' self. Dit is juis weerstand teen mag wat daartoe lei dat magsuitoefening altyd onvoltooid en onafgehandeld is. Maar mag self moet teen weerstand 'weer staan', self weer weerstand word. Daarom moet mag of weerstand teen mag nie gevrees of verheerlik word nie: dit verwys by Foucault in die middelfase van sy werk gewoon na 'n outomatiese tegnies-historiese proses (bv. Foucault 1975a:149, 1990b:105).

Meer teoreties: Wesenlik beskou Foucault mag as relasies tussen mense waar die een die ander se handelinge affekteer. Mag verskil van dwang of geweld, wat die liggaam fisies affekteer. Mag daarenteen, laat 'n subjek doen wat hy of sy andersins nie sou doen nie; dit beperk of wysig die subjek se wil - en hierdie beperking of wysiging is ' $n$ tegniese sosiale proses. Mag berus egter nie by 'n enkele subjek nie: eerder in institusionele ruimtes waarbinne subjekte opereer en deur mag gewysig of beperk word en self weer as agente vir wysiging en beperking ingespan word. Mag is dus nie geïndividualiseerd nie, maar juis deïndividualiserend van aard. Die 'masjien van mag' het nie 'n enkele operateur nodig nie: enige iemand kan ter enige tyd meewerk aan die opwekking van mag. Na hierdie outomatiese, anonieme en gedeïndividualiseerde proses verwys Foucault telkens as 'n 'tegnologie' (vgl. Foucault 1975a:148), 'n tipies middelfase uitdrukking in sy werk. Die een pertinente kwalifikasie van mag by die middel-Foucault is dus die anonimiteit of tegnisiteit daarvan. Sonder om nou daarop te kan ingaan, kan vermeld word dat mag by die latere Foucault 'n 'gesig' kry en skerper persoonlik-individualiserend omlyn word, wat trouens een van die duideliker breuke tussen die middel- en latere Foucault aandui.

Hierdie tegnologie het in terme van die algemene strekking in die middelfase van Foucault se werk 'n uitdaging vir die na-moderne mensheid geword: indien hierdie mensheid nog hoegenaamd en tersaaklik in die mensheid belangstel, wat iets geheel anders as ' $n$ gewaande kennis van die mensheid is. Die wetenskap lewe: maar die mens is dood. Na Heidegger, vir Foucault (1984:470) die 'wesenlike filosoof', sou 'n mens kon stel: Outentieke daar-wees het voor kunde, tegniek en dissiplinering in duie gestort. Daar is na die middel-Foucault geen (moderne) subjek meer nie. Dit is die somber implikasie van elke konsep in middel-Foucault se analises.

Daarom sou die werk gedurende die laaste fase van Foucault se loopbaan, vanaf 1978 tot 1984, rehabiliterend fokus op die 'voortgaande versorging van die Self', die etisering en estetisering van subjektiwiteit en uiteindelik 'n 'kritiese ontologie van die Self'. Tog is daar by die middel-Foucault reeds sprake van 'n Ander, onmoderne subjektiwiteit, in die helderheid van waansin, in die waansin van psigiatrie, in die vryheid van 'n gevangene, in die gevangeskap van bevrydes, in die gesondheid van neurotiese siekes en in die neuroses van psigiaters. In die argeologie en genealogie van hierdie onmoderne subjektiwiteit is reeds die middel-Foucault ten diepste 'n emansipatoriese denker.

\section{Erkennings \\ Mededingende belange}

Die outeur verklaar dat hy geen finansiële of persoonlike verbintenis het met enige party wat hom nadelig kon beïnvloed in die skryf van hierdie artikel.

\section{Literatuurverwysings}

Beukes, J., 1996, 'Michel Foucault en die historisering van Anderswees', HTS Teologiese Studies/Theological Studies 52, 233-251.

Beukes, J., 2002a, 'Ars erotica en die detrivialisering van die seksuele diskoers: 'n Aantekening by die seksualiteitsanalise van Michel Foucault', HTS Teologiese Studies/Theological Studies 58, 283-298.

Beukes, J., 2002b, 'Vanaf laat-strukturalisme na post-strukturalisme: 'n Kontekstualisering van Jean-François Lyotard se Discours, Figure', HTS Teologiese Studies/Theological Studies 58, 994-1010.

Beukes, J., 2004, 'Teenswoordige geskiedenis: Michel Foucault in gesprek met die teologie', HTS Teologiese Studies/Theological Studies 60, 883-899.

Beukes, J., 2005, 'Terreur, roes en ordes: Die monnik as blywende simbool van erns in die filosofie', HTS Teologiese Studies/Theological Studies 61, 1101-1129.

Beukes, J., 2008, 'Voices carry: An archaeology of the Hervormd approach', HTS Teologiese Studies/Theological Studies 64, 73-109.

Beukes, J., 2009a, 'Hamartia: Foucault \& Iran 1978-1979 (I Introduction \& Texts)', HTS Teologiese Studies/Theological Studies 65(1), Art. \#124. http://dx.doi. org/10.4102/hts.v65i1.124

Beukes, J., 2009b, 'Hamartia: Foucault \& Iran 1978-1979 (II Scholarship \& Significance)', HTS Teologiese Studies/Theological Studies 65(1), Art. \#125. http:// dx.doi.org/10.4102/hts.v65i1.125.

Brown, B. \& Cousins, M., 1994, 'The linguistic fault: The case of Foucault's archaeology', in B. Smart (red.), Michel Foucault: Critical Assessments II, pp. 186-208, Routledge, London.

Caputo, J.D. \& Yont, M., 1993, 'Institutions, normalization, and power', in J.D. Caputo $\&$ M. Yont (eds.), Foucault and the critique of institutions, pp. 3-26, Penn State $\& M$. Yont (eds.), Foucault and th
University Press, Pennsylvania.

Clegg, S., 1998, 'Foucault, power and organizations', in A. McKinlay \& K. Starkey (eds.), Foucault, management and organization theory: From Panopticon to technologies of the Self, pp. 29-48, Sage, London.

Cronin, J., 2001, Foucault's antihumanist historiography, Edwin Mellin, Lewiston.

Davidson, A.I., 1997, 'Structures and strategies of discourse: Remarks towards a history of Foucault's philosophy of language', in A.I. Davidson (ed.), Foucault and his interlocutors, pp. 1-23, Chicago University Press, Chicago.

Dosse, F., 1997, The history of structuralism, University of Minneapolis Press, Minneapolis.

Deleuze, G., 1994, 'Foucault and the prison', in B. Smart (ed.), Michel Foucault: Critical Assessments III, p. 268, Routledge, London.

Deleuze, G. \& Guattari, F., 1987, A Thousand plateaus - Capitalism and schizophrenia, University of Minnesota, Minneapolis.

Dreyfus, H.L. \& Rabinow, P., 1983, Michel Foucault: Beyond structuralism and hermeneutics, 2 nd edn., University of Chicago Press, Chicago.

Eribon, D., 1991, Michel Foucault, Faber \& Faber, London.

Ewald, F., 1992, 'A power without an exterior', in T.J. Armstrong (ed.), Michel Foucault: Philosopher, pp. 169-175, Routledge, New York,

Foucault, M., 1961, 'Madness only exists in society', in S. Lotringer (ed.), 1996, Foucault Live: Collected interviews, 1961-1984, pp. 6-9, transl. L. Hochroth, Semiotext(e), New York.

Foucault, M., 1965, Madness and civilization: A History of insanity in the Age of Reason, transl. R. Howard, Random House, New York.

Foucault, M., 1967, 'The discourse of history', in S. Lotringer (ed.), 1996, Foucault Live: Collected interviews, 1961-1984, transl. J. Johnston, pp. 19-32, Semiotext(e), New York.

Foucault, M., 1969a, 'Foucault responds to Sartre', in S. Lotringer (ed.), 1996, Foucault Live: Collected interviews, 1961-1984, transl. J. Johnston, pp. 51-56, Semiotext(e) New York.

Foucault, M., 1969b, 'The archaeology of knowledge', S. Lotringer (ed.), 1996, Foucault Live: Collected interviews, 1961-1984, transl. J. Johnston, pp. 57-64, Semiotext(e), New York.

Foucault, M., 1969c, 'The birth of a world', in S. Lotringer (ed.), 1996, Foucault Live: Collected interviews, 1961-1984, transl. J. Johnston, pp. 65-67, Semiotext(e), New York. 
Foucault, M., 1970, The Order of things: An Archaeology of the human sciences, transl. A. Sheridan Tavistock, London.

Foucault, M., 1971, 'Rituals of exclusion', in S. Lotringer (ed.), 1996, Foucault Live: Collected interviews, 1961-1984, transl. J.K. Simon, pp. 68-73, Semiotext(e), New York.

Foucault, M., 1972, The archaeology of knowledge, transl. A. Sheridan, Tavistock, London.

Foucault, M., 1973, The birth of the clinic: An Archaeology of medical perception, transl. A. Sheridan, Pantheon, New York.

Foucault, M., 1975a, 'From torture to cellblock', in S. Lotringer (ed.), 1996, Foucault Live: Collected interviews, 1961-1984, transl. J. Johnston, pp. 146-149, Semiotext(e), New York.

Foucault, M., 1975b, 'Schizo-Culture', in S. Lotringer (ed.), 1996, Foucault Live: Collected interviews, 1961-1984, transl. S. Lotringer, pp. 154-180, Semiotext(e) New York.

Foucault, M., 1976, 'The social extension of the norm', in S. Lotringer (ed.), 1996 Foucault Live: Collected interviews, 1961-1984, transl. L. Hochroth, pp. 196-199, Semiotext(e), New York.

Foucault, M., 1977a, Language, counter-memory, practice, transl. D.F. Bouchard \& S Simon, Blackwell, Oxford.

Foucault, M., 1977b, Discipline and punish: The birth of the prison, transl. A. Sheridan, Allen Lane, London.

Foucault, M., 1977c, 'Power affects the body', in S. Lotringer (red.), 1996, Foucault Live: Collected interviews, 1961-1984, transl. D.M. Herman, pp. 207-213, Semiotext(e), New York.

Foucault, M., 1977d, 'The end of the monarchy of sex', in S. Lotringer (ed.), 1996 Foucault Live: Collected interviews, 1961-1984, transl. D.M. Marchi, pp. 214-225, Semiotext(e), New York.

Foucault, M., 1978, The history of sexuality, I: The will to knowledge, transl. R. Hurley, Vintage, New York.

Foucault, M., 1980, 'Two Lectures', in C. Gordon (ed.) Michel Foucault: Power/ Knowledge: Selected interviews and other writings, 1972-1977, pp. 78-108, The Harvester Press, London.

Foucault, M., 1981a, 'Questions of Method', Ideology \& Consciousness 8, 3-14.

Foucault, M., 1981b, 'The order of discourse', in R. Young (ed.), Untying the text: A post structuralist reader, pp. 44-78, Routledge, London.

Foucault, M., 1984, 'The return of morality', in S. Lotringer (ed.), 1996, Foucault Live: Collected interviews, 1961-1984, transl. J. Johnston, pp. 465-473, Semiotext(e) New York.

Foucault, M., 1985, The history of sexuality, II: The use of pleasure, transl. R. Hurley, Vintage, New York.

Foucault, M., 1986, The history of sexuality, III: The care of the Self, transl. R. Hurley, Vintage, New York.
Foucault, M., 1990a, 'The minimalist Self', in L.D. Kritzman (ed.), 1990, Michel Foucault: Politics, philosophy, culture, transl. A. Sheridan, pp. 1-16, Routledge, Loucault
London.

Foucault, M., 1990b, 'On power', in L.D. Kritzman (ed.), 1990, Michel Foucault: Politics, philosophy, culture, transl. A. Sheridan, pp. 96-109, Routledge, London.

Foucault, M., 1990c, 'The dangerous individual', in L.D. Kritzman (ed.), 1990, Michel Foucault: Politics, philosophy, culture, transl. A. Sheridan, pp. 125-151, Routledge, London.

Foucault, M., 1990d, 'Confinement, psychiatry, prison', in L.D. Kritzman (ed.), 1990, Michel Foucault: Politics, philosophy, culture, transl. A. Sheridan, pp. 178-210, Routledge, London.

Fraser, N., 1981, 'Foucault on modern power: Empirical insights and normative confusions', Praxis International 1(3), 272-287.

Gutting, G., 1989, Michel Foucault's archeaology of scientific reason, Cambridge University Press, Cambridge, UK.

Hunter, B., 2010, 'A Foucauldian reading of the rules and practices in South African casinos', M Phil Thesis (Applied Ethics, with specialisation in the field of Social and Political Ethics), St Augustine College, South Africa.

Kendall, G. \& Wickham, G., 1999, Using Foucault's methods, Sage, London.

Kritzman, L.D. (ed.), 1990, Michel Foucault: Politics, philosophy, culture, transl. A Sheridan, Routledge, London.

Lotringer, S. (ed.), 1996, Foucault Live: Collected interviews, 1961-1984, transl. L. Hochroth \& J. Johnston, Semiotext(e), New York.

Macksey, R., 1972, The structuralist controversy, John Hopkins University, Baltimore.

Mahon, M., 1992, Foucault's Nietzschean genealogy: Truth, power and the subject, State University of New York Press, Albany, NY.

May, T., 1993, Between genealogy and epistemology, Penn State University Press, University Park.

Megill, A., 1985, Prophets of extremity: Nietzsche, Heidegger, Foucault, Derrida, University of California Press, Berkeley, CA.

Miller, J., 1994, The passion of Michel Foucault, Flamingo, London.

Paras, E., 2006, Foucault 2.0., Other Press, New York.

Prado, C.G., 1995, Starting with Foucault: An Introduction to genealogy, Westview Press, Boulder, $\mathrm{CO}$

Rabinow, P., 1984, 'Politics and Ethics', in P. Rabinow (ed.), The Foucault Reader, pp. 371-383, Pantheon, New York.

Rogerson, J.W., 2000, 'The potential of the negative: Approaching the Old Testament through the work of Adorno', in R. Carroll (ed.), Rethinking contexts: Rereading texts, pp. 24-47, Sheffield Academic Press, Sheffield.

Turner, B.S., 1995, 'The disciplines', in B. Smart (ed.), Michel Foucault: Critical Assessments IV, pp. 372-387, Routledge, London.

Visker, R., 1995, Michel Foucault: Genealogy as critique, Verso, London. 